\title{
Global Eocene tectonic unrest: Possible causes and effects around the North American plate
}

\author{
Carmen Gaina and Johannes Jakob \\ Centre for Earth Evolution and Dynamics, CEED, Department of Geosciences, \\ University of Oslo, Norway
}

\begin{abstract}
Many of our planet's "crises" were the result of sudden changes in plate tectonic
\end{abstract} configuration or catastrophic outbursts of volcanism caused by mantle plume impingement at the base of the lithosphere. At the Paleocene-Eocene boundary and in the Early Eocene several mantle plumes, continental collision and mid-ocean ridge subduction triggered a series of changes in seafloor spreading dynamics. We have constructed a detailed global model of oceanic lithosphere age and spreading rates for the 60 to $35 \mathrm{Ma}$ interval. We revise evidence for changes in seafloor spreading direction in the North Atlantic, Arctic and NE Pacific oceans. At least two periods of spreading rate highs, which are separated by sharp value decrease, occurred along the entire eastern North American plate boundary from C25 to C18 time (c. 57 to $40 \mathrm{Ma}$ ). The collision and incipient subduction of the Early Eocene Siletzia oceanic LIP may have caused the sharp decrease in spreading rate at C23 time in the Labrador Sea and north of Charlie-Gibbs fracture zone. The post C23 rapid Farallon slab-break-off and subsequent upper mantle flow upwelling may have led to further variations in North Atlantic spreading rates at C22-21 time. Eastward Pacific subduction may have resumed at c. $43 \mathrm{Ma}$ as indicated by a steady NE Pacific seafloor-spreading regime which resumed at or shortly after C21. The North Atlantic realm shows a delayed response to tectonic events west of North America, with an increase in spreading rate south of Charlie-Gibbs fracture zone from C20 to C18 time, followed by a steady decrease until the Oligocene. North American Late Paleocene-Early Eocene kimberlite magma that erupted more than $1000 \mathrm{~km}$ from its western plate boundary constitutes additional evidence that tectonic stresses due to changes in the mantlelithosphere interactions may have affected the entire plate, and therefore also its eastern boundaries. 
Keywords: Eocene tectonic events; plate motion changes; North Atlantic; Northeast

\section{Highlights}

1. Collision and subduction west of North America caused tectonic changes in North Atlantic

2. Farallon slab break-off initiated mantle upwelling and upper plate rotation

3. North American plate and mantle flow changes caused Eocene kimberlites eruptions

\section{Introduction}

Earth history is commonly characterized by long periods of steady-state evolution punctuated by catastrophic events that forced the global system to adapt to new configurations (e.g. Rona and Richardson, 1978). What causes major Earth's system turning points and how is our planet responding to them locally and globally through geological time are still unanswered questions. It has long been recognized that a major collisional and mountain building event, such as the India-Eurasia collision and the resulting Himalaya orogeny, can have severe implications on Earth's crustal structure, by forcing a re-accommodation of a considerable amount of tectonic stresses over long distances (e.g. Patriat and Achache, 1984). However, the timing of this collisional event is still debated (e.g. Aitchison et al., 2007; Najman et al., 2017) and classical modelling of this event's effect on plate reorganisations in neighbouring areas (like the Pacific Ocean) minimized its importance (Richards and Lithgow-Bertelloni, 1996).

60 Other major events that impacted Earth's crust and subsequently the climate and life

61 have been attributed to excessive volcanism, possibly generated by massive mantle

62 plumes from Deep Earth, which resulted in so-called Large Igneous Provinces (LIPs)

63 on the Earth's surface. Recent studies have attempted to quantify (Cande and

64 Stegman, 2011) and model (Iaffaldano et al., 2018; van Hinsbergen et al., 2011) the

65 effect of mantle plumes on Cenozoic plate motions variations in the Indian Ocean.

66 The results confirm that mantle plumes are potential candidates to explain some plate

67 motion changes, but disagree on the vigor of this trigger in time. 
Apart from the LIP events that caused massive havoc in Earth's system, there are many other changes that have been registered by Earth's outer layers, but their causes and exact succession of events and associated consequences are not yet established. For example, the oceanic crust in the Pacific realm and elsewhere has witnessed changes in the tectonic plate motions before, during, and after the well-known Hawaiian-Emperor volcanic chain "bend", with the clearest changes spanning c. 10 Myrs, from 55 to 45 Ma (e.g. Sharp and Clague, 2006; Torsvik et al., 2017). Several other Paleocene-Eocene tectonic events have been registered in the Pacific realm (Whittaker et al., 2007; (Seton et al., 2015; Torsvik et al., 2017) postulating that the subduction of an active mid-ocean ridges under Japan (e.g. Whittaker et al., 2007), or terrane collision with NE Asia (Domeier et al., 2017) led to a change in the Pacific plate motion, and that may have also been recorded by the tectonics of neighbouring plates.

To better understand how our planet's turning points were caused and whether sudden changes in plate tectonic configuration could have been related to continent collision, mountain building, major changes in the subduction geometry or catastrophic outbursts of volcanism often caused by mantle plume impingement at the base of the Earth's lithosphere, we revise the Eocene tectonic unrest which is imprinted in the world's oceanic lithosphere. A more detailed set of Eocene oceanic crust timelines (isochrons and age-grid) are constructed based on results from vintage and recent studies that dated the oceanic lithosphere from magnetic anomalies. We chose to analyse in more detail the unusual abrupt Eocene changes in seafloor spreading direction and spreading rates around the North American plate. Finally, we speculate on possible connections between subduction in the NE Pacific, mantle plume activity in the North Atlantic, and the evolution of North American oceanic lithosphere in the Eocene.

\section{Data and methods}

In this study, we rely on published magnetic anomaly and seafloor fabric (mainly fracture zones) identifications in the oceanic realm. A comprehensive global compilation of marine magnetic anomalies identified in the last few decades in all major oceanic basins, was published by Seton et al., (2014) (Fig. 1A). We complement this dataset with few more regional marine magnetic anomaly identifications shown in Fig 1: 322 picks by Petronotis et al., (1994) in the Pacific 
102 Ocean (Fig. 1, B1), 2255 picks by Luis and Miranda, (2008) in the Atlantic Ocean 103 (Fig. 1, B2), 563 picks by Roest and Srivastava, (1989), and 145 magnetic anomaly 104 identifications in the Labrador Sea (C20 and C21 from Gaina et al., 2002, and new 105 C16y magnetic identifications) (Fig. 1, B3). A number of magnetic anomaly picks 106 from the NE Pacific already collated in the Seton et al., (2014) global compilation 107 have been checked and/or reinterpreted (Fig. 1, B1 and Fig. S1). All magnetic 108 anomaly identifications are assigned Cenozoic ages according to the Ogg, (2012) 109 geomagnetic timescale (Table 1).

110 The magnetic anomaly identifications (Table 1) and fracture zone segments 111 (Matthews et al., 2011) corresponding to oceanic lithosphere between 58 and $38 \mathrm{Ma}$

112 old, were used for constructing denser isochrons at Chrons (C) 25, 24, 23, 22, 21, 20

113 and 18, filling the gap between C25, C21 and C18 available in published global 114 models (Müller et al., 2008; Seton et al., 2012; Muller et al., 2016). In the Labrador 115 Sea, C26, and C27 were also added to the global isochron set. The rotation parameters 116 from Seton et al., (2012) have been checked, modified and complemented for the 117 Eocene time by visually matching magnetic anomaly identifications from conjugate 118 flanks in the GPlates (www. gplates.org) open-source application. A present day 119 global oceanic lithospheric age and associated spreading-rates grids (Fig. 2) were 120 constructed using the newly interpreted isochrons and the modified rotation 121 parameters, following the interpolation technique outlined by (Müller et al., (2008) 122 with a gridding resolution of 0.1 degrees.

124 3. Results

125 3.1. Eocene tectonic unrest in global oceans illustrated by seafloor spreading 126 variations

127 Many facets of the oceanic basin development are keys to better understand planetary 128 changes. Oceanic crust fabric reveals how tectonic plates moved and records the age, 129 direction and rate of seafloor spreading, together with any complex processes 130 associated with this evolution. The global oceanic basins are also prized witnesses of 131 lithosphere-mantle interactions through numerous volcanic edifices built on top of 132 normal oceanic crust.

133 The detailed global model of kinematic parameters, derived from the new global 134 database of magnetic anomaly identifications, was used to extract parameters that 135 describe relative plate motions in the Paleocene-Eocene time-span (c. 65 to $35 \mathrm{Ma}$ ). 
136 We have computed stage-pole rotations (Table S1) based on the dense set of 137 isochrons (C25 to $\mathrm{C} 17$ ) for several major plate tectonics pairs, and used this 138 information to illustrate the timing and amount of change between plate pairs by 139 showing variations in the angular rotation rates and spreading directions (Figs. 3, S2).

140 The first-order observation is that more abrupt and large variations in seafloor141 spreading directions and rates are linked to smaller plates, which are attached to 142 subducted slabs, like the Juan de Fuca, Nazca and Indian plates (Fig. 3). The three 143 plates system North America-Greenland-Eurasia, which was active in the Eocene 144 time, makes an exception from this simple correlation, showing considerable changes 145 in spreading directions post-55 Ma (Fig. 3). We therefore are further analysing the 146 structure of the Eocene oceanic lithosphere around North America aiming to obtain 147 more details about the timing and amount of changes in relative plate motion.

\subsection{Oceanic crust around the North American plate since the Eocene}

\subsubsection{North America-Eurasia: the Eurasia Basin}

The opening of the Eurasia Basin was the result of relative plate motion between North America and Eurasia (e.g. Gaina et al., 2002). The Lomonosov Ridge microcontinent (Fig. 4) became part of the North American plate in early Cenozoic

154 (e.g. Dossing et al., 2017), and was subsequently rifted from the northern Eurasia 155 margin (e.g. Srivastava and Tapscott, 1986), followed by seafloor spreading in the 156 Eurasia Basin. This was contemporaneous with the opening of the NE Atlantic, both 157 basins having c. 55-0 Ma old oceanic lithosphere, as inferred from linear magnetic 158 anomalies (Alvey et al., 2008; Brozena et al., 2003; Glebovsky et al., 2006; Gaina et 159 al., 2015; Gaina et al., 2017). We have revised the isochrons in the Eurasia Basin 160 based on Gaina et al., (2002) and Ehlers and Jokat, (2009), and merged this model 161 with the NE Atlantic isochrons (Gaina et al., 2017) .

162 The slow and ultra-slow spreading regimes and the absence of fracture zone 163 makes it difficult to identify changes in spreading direction in the Eurasia Basin. 164 Dramatic slow down in the spreading rate has been identified from magnetic 165 anomalies at C18 and at C13 (e.g. Glebovsky et al., 2006). Post C22 time, mid-ocean 166 ridge relocation and/or a change in the magnetic anomaly spreading direction in the 167 eastern Eurasia Basin, plus evidence for compression in the East Siberian Shelf, led 168 Gaina et al., (2015) to suggest that the tectonic stresses generated by the northward169 moving Greenland and associated Eurekan deformation may have propagated further 
away into the Arctic and affected not only the North American Ellesmere Islands, but also small areas of the easternmost Eurasia Basin and the East Siberian shelf. Note that the Eurekan deformation (or orogeny) had several phases that resulted in a number of intra-continental deformation zones in the Canadian Arctic Archipelago, Svalbard and north and northeast Greenland (for a review, see Piepjohn et al., 2016).

\subsubsection{North America-Greenland: Labrador Sea and Baffin Bay}

After a prolonged time of continental extension and possible hyperextension from Mid to Late Mesozoic, seafloor spreading commenced in the Labrador Sea and Baffin Bay probably at C30-C27 time (66.4-62.2 Ma, e.g. Chalmers et al., 1999; Oakey and Chalmers, 2012) (Fig. 5). In the smaller Baffin Bay, seafloor spreading started later than in the Labrador Sea, but before C25y (e.g. Roest and Srivastava, 1989). A c. 30 degrees counter-clockwise change in seafloor spreading direction post C25 (57. $1 \mathrm{Ma}$ ) has been reported by Roest and Srivastava, (1989) from the magnetic anomaly pattern (Verhoef et al., 1996) and the orientation of fracture zones visible in the gravity anomaly data (Sandwell et al., 2014) (Fig. 5). At the same time, spreading direction also changed in the Baffin Bay, from E-W to SE-NW (Suckro et al. 2012). In the neighbouring NE Atlantic, break-up and seafloor spreading initiation between Greenland and Eurasia occurred at C25-24 (e.g. Gaina et al., 2009; Gaina et al., 2017; Kristoffersen, 1978; Pitman and Talwani, 1972), after the $2^{\text {nd }}$ phase of the North Atlantic Igneous Province (NAIP) formation, a magmatic event that has been invoked as the triggering mechanism for the counter-clockwise rotation of the North AmericaGreenland seafloor spreading system.

3.2.3. North America-Eurasia (Rockall-Porcupine): North Atlantic between Bight fracture zone and King's Trough $\left(46^{\circ} \mathrm{N}\right)$

Seafloor spreading in this region started in mid-Cretaceous time (around c. C34, 83.6 Ma, Roest and Srivastava, 1991) and continued northwestwardly into the Labrador Sea from C30. A seafloor spreading change in direction at C25 is seen very prominently on both magnetic and gravity anomaly maps (Fig. 5). South of CharlieGibbs fracture zone, the change in seafloor spreading direction is more gradual from C24 to C21, as shown by the magnetic lineation "fan" pattern and onset of additional fracture zones between 49 and $52^{\circ} \mathrm{N}$ (Fig. 6). A small magmatic province just south of Charlie-Gibbs fracture zone, named the "West Thulean Rise" and its conjugate on the Eurasia plate, the "East Thulean Rise", have formed between 60 and 50 Ma due to 
204 excess volcanism at mid-ocean ridge possibly hot-spot related (Louden et al., 2004). 205 Magnetic anomaly interpretation indicate that this feature sits on 54 - 49 Ma old 206 oceanic crust (C24-C22), and it may be related to the change in spreading direction 207 that occurred in that time period. We therefore suggest that the duration of volcanism 208 that formed those features could not have been more than $5 \mathrm{myr}$, half of the value 209 proposed by Louden et al., (2004).

210 3.2.4. North America-Iberia: North Atlantic between King's Trough $\left(46^{\circ} \mathrm{N}\right)$ and 211 Azores

212 This oceanic domain formed since the Cretaceous, when continental break-up put an 213 end to a long period of hyperextension between Newfoundland and Iberian margins 214 (e.g. Nirrengarten et al., 2017; Peron-Pinvidic and Manatschal, 2009). The Early 215 Eocene changes in spreading direction are not visible in the magnetic data, and there 216 are no fracture zones in this $650 \mathrm{~km}$ long north-south spreading corridor. A detailed 217 interpretation of magnetic anomaly data by Luis and Miranda, (2008) was used to 218 construct the $\mathrm{C} 25-\mathrm{C} 18$ isohrons, which contributed to the global new age and 219 spreading rates grids shown in Fig.2.

220 3.2.5. North America-Africa: North/Central Atlantic between the Azores and Kane 221 fracture zone

222 The earliest break-up of Pangaea is dated c. $200 \mathrm{Ma}$ and seafloor spreading as old as 223 180-190 Ma was formed between the North American margin and the NW Africa 224 (e.g. Labails et al., 2010). Seafloor spreading in this domain is highly segmented, with 225 about six major and many more smaller fracture zones crossing the c. $2600 \mathrm{~km}$ long 226 oceanic crust segment (e.g. Müller et al., 1999; Müller and Roest, 1992). The Eocene 227 changes in spreading direction were well recorded by major fracture zones showing 228 two major "kinks" at (or before) C25 (Tucholke, 1988) and at C20 (Fig. 7). New 229 fracture zones were formed between the Atlantic and Kane fracture zones at c. C25 230 time and were active until C20 time (Fig. 7).

\section{3.2.6. North America- Farallon/ Juan de Fuca plate}

232 Detailed maps of ages and structure of NE Pacific oceanic lithosphere have been 233 published in early 70s and 80s (e.g. Atwater and Menard, 1970 and references herein, 234 Caress et al., 1988; Stock and Molnar, 1988). According to the kinematic models 235 proposed by these early studies, the subducting Farallon plate has been fragmented in 236 several smaller plates (e.g. Menard, 1978) starting in the Cretaceous with the 237 formation of Kula plate (e.g. Lonsdale, 1988). In the Eocene, Farallon's northeastern 
part was called the "Vancouver" plate (Menard, 1978), and for times younger than

239 Miocene (c. $28 \mathrm{Ma}$ ) its remains were named the "Juan de Fuca" plate (Atwater, 1970),

240 a tectonic block bounded to the east by the North American trench, to the south by

241 Mendocino fracture zone, and to the west by a mid-ocean ridge with the Pacific plate.

242 In fact, from a plate kinematic point of view, the Vancouver and Juan de Fuca plates

243 should be treated as one plate that changed its size and plate boundary geometry since

244 the Eocene to present day. We therefore keep the "Juan de Fuca" name for the

245 Eocene-present tectonic plate conjugate to the Pacific plate north of the Mendocino

246 fracture zone.

247 Caress et al., (1988) noted that north of the Surveyor fracture zone the change in 248 spreading direction occurred at C23 time, and in the region situated between the 249 Surveyor and Mendocino fracture zone, the clockwise rotation was delayed to C22 250 time. The formation of the Juan de Fuca plate may have been triggered by or 251 coincided with a C24-21 change in spreading direction mentioned by Caress et al., 252 (1988). Subsequent geophysical data collection and compilation confirmed earlier interpretation of the NE Pacific tectonic structure and timing of changes in spreading direction with various degrees of precision. For the time interval discussed here, Rosa and Molnar, (1988) interpreted magnetic anomaly C25 and C21, and a very rough outline of fracture zone location; Wright et al., (2015) shows the magnetic anomaly identifications compiled by Seton et al., (2014), which include chrons 25, 24 (young and old), 22, 21 and 20; whereas McCrory and Wilson, (2013) shows a complete set of isochrons from C25 to C20 (with C23 missing in the region between Surveyor and Mendocino fracture zones).

261 Newly published global datasets: magnetic gridded data (e.g. the NOAA latest global 262 EMAG2v3, Meyer et al., (2017), gravity data (e.g. Sandwell et al., (2014), and high 263 resolution multi-resolution bathymetry data (Ryan et al., 2009) and 264 http://www.marine-geo.org/portals/gmrt/) are inspected in this study for details of 265 seafloor fabric useful to better determine the location and timing of seafloor spreading reorientations (Figs 8,9). Free air gravity anomaly and bathymetry grids show that the

267 oldest end of fracture zones Sila and Sedna are dated as C21 (47. 3Ma), which may 268 indicate the beginning of a more steady seafloor spreading in NE Pacific after mid269 ocean ridge reorientations. According to the magnetic anomaly data (Figs. 8, 9), 270 changes in seafloor spreading direction and subsequent adjustments were recorded by 271 the oceanic lithosphere north of Mendocino fracture zone at $\mathrm{C} 23 \mathrm{o}-\mathrm{C} 22 \mathrm{y}$ (50.628- 
48.566 Ma), and at c. C24o-23y time (51.833-52.620 Ma) north of Surveyor fracture zone (Fig. 8A). South of the Mendocino fracture zone, the C25-C20 isochrons show

274 the same N-S orientation with no clear signs of changes in spreading direction in that 275 time interval (Fig. 8). However, high resolution multibeam data across the Murray 276 and Molokai fracture zones and gravity anomalies show a transition from extension to 277 compression at $\mathrm{C} 22$ time (Fig. 9C-F), indicating that the clockwise rotation of the 278 plate boundary between the Pacific and Farallon/Juan de Fuca plates is also 279 documented by regions south of the Mendocino fracture zone.

280 From published and interpretation of latest available geophysical datasets in the NE 281 Pacific we conclude that a change in seafloor spreading direction occurred at C24282 C23 time north of the Surveyor fracture zone and at C22 time south of it and up to the $28323^{\circ} \mathrm{N} /$ Molokai fracture zone system. A set of new fracture zones were developed 284 north of the Surveyor fracture zone at C21 time and this may mark the end of the NE 285 Pacific seafloor spreading reorientation that started at C24-C23 time.

\subsection{Eocene seafloor-spreading rate variations around the North American plate}

288 Changes in spreading directions inferred from orientation of linear magnetic anomaly and fracture zone segments, and variations in seafloor-spreading rates, indicate modifications in tectonic plates dynamics. In the previous section, we have reviewed major changes in the spreading direction of various segments of the Eocene plate

292 boundaries around the North American plate. Here we are using the newly created 293 Eocene age-grid and spreading-rate grids (Fig. 2) to calculate seafloor-spreading rates 294 for North American plate and conjugate flanks. We created a series of flowlines in each of the oceanic sectors described above at the same geological times used to construct the new isochrons (Fig. 10). We used these flowlines to extract the spreading rate values along segments which follow the paths of relative motions 298 between two plates (Fig. 10A).

299 In the North Atlantic and Arctic, we observe common trends in two separate seafloorspreading value groups: the first one from profiles in the Eurasia Basin, NE Atlantic and Labrador Sea (we call it the "northern" group), and the second one from profiles south of Bight fracture zone ("southern" group) (Fig. 10B). For comparison between seafloor spreading rate variation in the northern and southern sectors, we are also

304 showing the NE Atlantic profile from the northern group together with the southern 305 profiles (Fig. 10B). Two major seafloor-spreading rate increases span the time 
intervals at or between chrons $\mathrm{C} 25$, or $\mathrm{C} 25-24$, and at $\mathrm{C} 22-21$ (northern group) or

307 C22-20 (or later at C20-18) for the southern group. Two spreading rate drop intervals are at C23 (northern group) or at C22-21 (southern group), and at C20 (northern group) or C18 (southern group) (Fig. 10B).

In the Pacific Ocean, we constructed a profile through the Juan de Fuca-Pacific plate, and through the preserved Pacific flank of the Pacific-Farallon spreading system (Fig. 10C). A modest increase in seafloor-spreading rate occurred in both spreading sectors at C25-24, followed by a rate decrease at C23 (Fig. 10D). At C22-21, the seafloor spreading rate increased by $50 \%$ indicating a severe change of this spreading system.

\section{Discussions}

317 According to published regional kinematic models (e.g. Cande et al., 2011; Croon et 318 al., 2008; Gaina et al., 2009; Whittaker et al., 2007), and our present analysis, a global 319 Eocene tectonic "unrest" is recognized in the oceanic lithosphere structure with an 320 Early Eocene pervasive set of events located in the northern hemisphere, where it 321 affected the NE Pacific, North Atlantic and the Arctic region. Here we have presented 322 in more detail changes in seafloor spreading direction and rates of plate boundaries 323 around the North American plate. At least two periods of increase in seafloor 324 spreading rates in the North Atlantic (at C25 and at C22, Fig. 10) coincide with 325 changes in spreading directions (Figs. 3, 5, 6). A decrease in spreading rates at C23 in 326 the North Atlantic is contemporaneous with a clockwise re-orientation of the midocean ridge in the NE Pacific (Fig. 8), the formation of the Juan de Fuca plate, and the amalgamation of the Cordilleran terranes to the growing western North American margin at about $51 \mathrm{Ma}$ (Enkin, 2006). In the following we attempt to briefly list the main tectonic and magmatic events in the two oceanic realms, NE Pacific and North

331 Atlantic, and suggest correlations between these events and the dynamics of oceanic

332 lithosphere formation to the west and east of North America.

333 4.1. Paleocene-Eocene Volcanism and Large Igneous Provinces (LIPs) in North Atlantic and NE Pacific

335 The North Atlantic Igneous Province was mostly emplaced during the Paleogene (e.g. 336 Saunders et al., 2007) and had two extensive volcanic episodes, at c. 63-61 and 56 337 Ma. Magmatic rocks of NAIP's $1^{\text {st }}$ and $2^{\text {nd }}$ phases have been encountered both on338 land and offshore in the Labrador Sea, Baffin Bay, and NE Atlantic (e.g. Saunders et 339 al., 2007). The geochemical signature of magmas resulted from both main NAIP 
340 episodes indicates a mantle plume origin (e.g. Storey et al., 2007). After a period of 341 hyperextension and transitional crust formation, "normal" seafloor spreading in the 342 Labrador Sea may have begun just after the $1^{\text {st }}$ NAIP event (at C27, e.g. Chalmers et 343 al., 1995). Continental break-up between Greenland and Eurasia shortly followed the 344 2nd NAIP event just before C24 (e.g.White, 1992; Gaina et al., 2017). However, 345 several instances of Eocene post-break-up magmatism have been observed in both 346 Baffin Bay/Labrador Sea (Nelson et al., 2016) and NE Atlantic (Tegner et al., 2008), 347 and these minor volcanic episodes were linked to changes in plate boundary 348 orientations (Nelson et al., 2016; Gaina et al., 2009).

349 Basaltic rocks found in coastal Oregon, Washington, and southern Vancouver Island 350 from about 43 to $48^{\circ}$ northern latitude, are remnants of an Eocene oceanic LIP, 351 Siletzia, formed on the Farallon/Juan de Fuca and conjugate Kula/Resurrection plates 352 and later accreted onto North America. This province, which includes the Siletz River 353 Volcanics of Oregon, the Crescent Formation of Washington, and the Metchosin 354 igneous complex of southern Vancouver Island (here simplified as Siletzia="S" and 355 Crescent $=$ " $C$ " terranes, Fig. 11 inset figure) has been described since early 80 s (e.g. 356 Duncan, 1982) and lately revisited by studies evaluating its extent, age, and 357 geochemical composition (e.g. Eddy et al., 2017; Phillips et al., 2017; Wells et al., 358 2014)(Fig. 11). Ar-Ar ages indicate that Siletzia was formed at 56-49 Ma, and 359 accretion was completed between 51 and $49 \mathrm{Ma}$ (Wells et al., 2014), or slightly later 360 at c. 44 Ma (Eddy et al., 2017). Davis and Plafker, (1986) suggested that the 361 geochemical signature and the Eocene reconstructed position of this oceanic plateau, 362 show that Siletzia formed at a ridge-mantle plume junction, for example as an 363 interaction between the Yellowstone mantle plume and the NE Pacific mid-ocean 364 ridge, a model adopted by many studies published subsequently (e.g. Phillips et al., 365 2017). Another remnant of this LIP, formed in the proximity of the Kula/Farallon 366 mid-ocean ridge plate in the Eocene (Davis and Plafker, 1986), and subsequently 367 transported along the western North American margin until it accreted to southeast 368 Alaska, is now part of the Yakutat terrane ("Y" in Fig. 11 inset figure).

369 Several studies indicate that the arrival of a mantle plume at the base of the 370 lithosphere results not only in abundant volcanic eruptions, but also may disrupt 371 previous plate motion directions. According to Cande and Stegman, (2011) and van 372 Hinsbergen et al., (2011), the Early Cenozoic arrival of a mantle plume under the 373 Indian Ocean lithosphere influenced the African and Indian plate motion inducing a 
rotation in the African plate and a northward acceleration of the Indian plate. It is well accepted now that in the NE Atlantic, the $2^{\text {nd }}$ phase of NAIP magmatism led to breakup and seafloor spreading (Srivastava and Tapscott, 1986) and possibly to the change in seafloor spreading direction and rate in the Labrador Sea and Baffin Bay at C25-24 (e.g. Roest and Srivastava, 1991). The geophysical data indicate that an increase in seafloor spreading rate occurred at $\mathrm{C} 24$ time in the oceanic domain south of the Charlie-Gibbs fracture zone (Fig. 10), slightly delayed from the Labrador Sea change in spreading direction. However, it is not clear why seafloor-spreading rates suddenly dropped south of the Charlie-Gibbs fracture zone at C23 time (and at C22-21 in the "southern" segment, respectively). We note however that this is also the time when the Farallon plate, north of Mendocino Fracture Zone, has established a new spreading direction, presumably after a tectonic event at pre-C23 time that also led to a plate fragmentation. From these simple observations, one can deduce that the North Atlantic mantle plume activity which caused pervasive volcanism and break-up between Eurasia and Greenland, was also the cause of changes in North Atlantic plate motion at $\mathrm{C} 25-\mathrm{C} 24$ time. Subsequent plate motion changes at C23-C21 time may have been linked to plate boundary adjustments west of North American plate. To shed light on a possible correlation between the subduction dynamics west of the North American plate and observed changes in spreading rates and directions in the North Atlantic, we shortly review the Eocene NE Pacific subduction history.

\subsection{NE Pacific subduction history in the Eocene}

During the Cretaceous and Early Paleocene (from c. 140 to $60 \mathrm{Ma}$ ), the North American craton, was more or less standing still with respect to the Earth's spin axis, but began drifting during the 60 to $50 \mathrm{Ma}$ interval, as shown by the Apparent Polar Wander path of Torsvik et al. (2012). While on the eastern side of North American plate, rifting and seafloor spreading was active since the Cretaceous, on its western side subduction and terrane accretion modified its lithosphere and the underlying mantle for a much longer time.

The Farallon plate had a long history of subduction west of North America since the Jurassic, and its eastern plate boundaries could be partially restored from knowledge about various Cordillera terrane motion and amalgamation, arc volcanism (e.g. Wells, 1984; Cowan, 2003; and McCrory et al., 2009), and more recently by using the increasingly detailed seismic tomographic models (e.g. Sigloch et al., 2008; Pavlis et 

continent, or oceanward, as some studies proposed recently. For example, Sigloch and

410 Mihalynuk, (2013) suggests that at $55 \pm 7$ Ma the North American plates encountered 411 and overridden an island-arc formed by NE Pacific intra-oceanic subduction. 412 Following this event, the trench stepped westward and became the present-day 413 Cascadia subduction.

414 According to paleomagnetic data, the assemblage of the Cordillera terranes to the 415 North American craton was completed by c. 51-50 Ma (Enkin, 2006). But around that 416 time, mid-ocean ridge subduction (e.g. Breitsprecher et al., 2003), and oceanic plateau 417 obduction (e.g. McCrory and Wilson, 2013; Phillips et al., 2017; Wells et al., 2014), 418 followed by additional terrane accretion (e.g. Sigloch and Mihalynuk, 2013) and/or 419 slab break-off may have triggered changes in the subduction regime along the western 420 North American plate, most likely around $50 \pm 5$ Ma.

421 Several studies proposed that in the Early Eocene time the Kula plate broke in several 422 smaller plates (Resurrection and Eshamy, as suggested by Haeussler et al., (2003) and 423 Madsen et al., (2006), respectively), a plate geometry that can explain Eocene near424 trench magmatism whose geochemical signature indicates slab window formation 425 simultaneously along the southern Alaska and the Cascadia margins. This complex 426 plate kinematics would therefore account for one or several active mid-ocean ridge 427 subductions and oceanic plateau accretion between c. 56 and $42 \mathrm{Ma}$ (e.g. Haeussler et 428 al., 2003; Wells et al., 1984; Madsen et al., 2006; Wells et al., 1984). McCrory and 429 Wilson, (2013), who used detailed magnetic anomalies of oceanic crust and 430 reconstructed on-land geology, postulated that fragments of the oceanic Resurrection 431 and Farallon plates, which were modified by the interaction with a mantle plume 432 (presumably the Yellowstone hotspot), docked against the western North American 433 margin already at $53 \mathrm{Ma}$ to form Siletz and Crescent basement terrane. Their 434 kinematic model considers that the Eocene part of the Yakutat terrane, that has the 435 same age, geochemistry and thickness as the Crescent terrane, is a captured fragment 436 of the Resurrection thickened oceanic plate that has subducted and obducted SW of 437 Alaska from $40 \mathrm{Ma}$ onward.

438 Studies of subducted slabs under North America revealed several gaps in the 439 subducted material identified in tomographic models. In particular, two distinct slab 440 gap boundaries that may have been created in the Cenozoic, are particularly 441 mentioned by Sigloch et al., (2008) and Sigloch, (2011): the SSW-NNE "Slab Gap", 
north of the inland projection of the Mendocino Fracture Zone, and the NNW-SSE

443 "Big Break" (Fig. 11). The "Slab Gap" is interpreted to be a tear in the subducting 444 slab seen as deep as $1100 \mathrm{~km}$, and presumably having an age older than $50 \mathrm{Ma}$ 445 (Sigloch et al., 2008). Sigloch, (2011) tentatively dated the "Big Break" as Paleocene446 Eocene (60 to $40 \mathrm{Ma}$ ) suggesting a trench rollback slowing that may have been 447 caused by slab break-off at the trench (at c. $60 \mathrm{Ma}$ ), or in the upper mantle (at c. 50 $448 \mathrm{Ma}$ ), and therefore pointing to a possible link between a major plate reorganization 449 and changes in the subduction dynamics. A recent study (Dostal et al., 2018) shows 450 that the petrology and geochemistry of Eocene (55-45 Ma) calc-alkaline volcanic 451 rocks found in southern and central British Columbia and adjacent United States (part 452 of the Challis-Kamloops belt ("C-KV" in Fig. 11), together with tomographic images 453 of regional underlying mantle may indicate that a portion of the Siletzia LIP (named 454 Yellowstone oceanic plateau in their study) underwent flat subduction and 455 underthrusting under western North America.

456 To illustrate the Eocene plate kinematics of the North American plate and the 457 underlying mantle structure at depths which may have preserved clues about plate 458 boundaries for that time interval, we show plate reconstructions using our global 459 refined isochron set and rotations (see section 2) in an absolute mantle reference 460 frame (Doubrovine et al., 2012) (Fig. 11 left panels), together with locations of the 461 most robust mantle slabs imaged by 14 tomographic models as described by Shephard 462 et al., (2017) (Fig. 11 right panels). The so-called "vote-maps" use a statistical method 463 for identifying the most common robust features (in this case positive anomalies 464 interpreted as subducted slabs) in 14 different global tomographic models based on 465 both $\mathrm{P}$ and $\mathrm{S}$ waves. Correlating surface kinematics with subducted slabs imaged by 466 tomographic models require knowledge about slab sinking rates and orientation 467 relative to the surrounding mantle. Numerous studies about this topic have been 468 published and so far there is no consensus for a general model that would globally 469 assign sinking rates based solely on slab age, mainly because both observations and 470 modeling show that there is a large spectrum of these values depending on many other 471 factors, not only sinking plate age (e.g. Goes et al., 2017; Stegman et al., 2010). 472 Shephard et al., (2017)'s study shows that the age of subducted slabs in the upper 473 lower mantle (700 to $1100 \mathrm{~km}$ ) may correspond to 40 to 100 myrs old slabs that sank 474 with a constant slab sinking rates of $1-2 \mathrm{~cm} / \mathrm{yr}$, respectively. We therefore have first 
visually inspected the upper lower mantle vote-maps (Shephard et al., 2017) without having an apriori slab age-depth correlation. These maps (Fig. 11, right panels and

477 Fig. S3) show a very clear change in the subducted slab distribution between the 1100 and $700 \mathrm{~km}$ depth. Most remarkably is the growing slab gap visible north of the observed "Slab Gap" boundary described by Sigloch et al., (2008). This region, named here as the "Northern Slab Gap", to avoid confusion with the "Slab Gap" boundary of Sigloch et al., (2008), coincides with the area affected by Eocene slabwindow magmatic activity described by many studies (e.g. Cowan, 2003; McCrory et al., 2009). South of the "Slab Gap" boundary, another slab-gap region, named here the "Southern Slab Gap", coincides with the position of the slab window region mapped by Breitsprecher et al., (2003) using geochemical composition of the Eocene igneous rocks from northwestern US and British Columbia.

487 In a mantle absolute reference frame, our NE Pacific kinematic model predicts that segments of the Farallon/Juan de Fuca - Kula/Resurrection active mid-ocean ridge intersected/subducted under the Late Paleocene-Early Eocene western North American trench in a location just south of the "Northern Slab Gap" region. The northward motion of the subducting active mid-ocean ridge until c. $40 \mathrm{Ma}$ is well aligned with the absence of subducted material imaged by the combined tomographic models (shown as "vote-maps", Fig. 11). The 57 Ma reconstruction also shows that the position of a fixed Yellowstone hotspot is in the proximity of the subducting mid ocean ridge, and able to produce large-scale volcanism due to ridge-hotspot interaction, a postulated mechanism for the formation of Siletzia LIP (e.g. Johnston and Thorkelson, 2000; McCrory and Wilson, 2013; Wells et al. 2014). Note that the surface location of a hotspot may be uncertain due to the horizontal drift resulted from the mantle plume tilt in an advecting mantle. Doubrovine et al., (2012) calculated about $250 \mathrm{~km}$ of eastward drift for the Yellowstone hotspot in the last 16 myrs, which

502 The outline of Siletzia LIP extent is adopted after Wells et al. (2014)'s reconstruction at $55 \mathrm{Ma}$, and we model how the conjugate blocks of this LIP may have been transported NE and SE by the Kula/Resurection and Farallon/Juan de Fuca plate respectively (Fig. 11). Uncertainties of hotspot's position relative to the mid-ocean ridge and North American plate are due to a series of factors including relative and absolute motion models and the geometry of reconstructed continental margin. The

508 location of the North American continent is shown with its present-day coastlines, and 
509 its western margin may have been further east if Cenozoic extension would be 510 reconstructed. The Yellowstone mantle anomaly is believed to ascend from mid511 mantle, as a slow region was imaged between 500 and $1000 \mathrm{~km}$ (e.g. Sigloch et al., 512 2008). Although many other hypotheses have been put forward to explain

513 Yellowstone-related magmatism on continental North America since $17 \mathrm{Ma}$ (e.g. 514 Fouch, 2012), the coincidence between the reconstructed Siletzia LIP location at its 515 time of inception (around $56 \mathrm{Ma}$ ) near a mid-ocean ridge, and the observed lower end 516 of a slow mantle anomaly at $900-1000 \mathrm{~km}$ depth connect the Eocene surface volcanic 517 activity with the upper lower mantle plume root and confirm the longevity of the 518 Yellowstone hotspot (as suggested by the geochemical composition and the age of 519 Siletzia LIP (e.g. Phillips et al., 2017; Wells et al., 2014). Based on the above520 discussed reasons, we link the 56-57 Ma absolute plate tectonic reconstruction to the 521 mantle configuration at $1000 \mathrm{~km}$ depth. After the formation and obduction of the 522 Siletzia plateau between 56 and c. $44 \mathrm{Ma}$, subduction may have resumed west of the 523 accreted plateau at $c$. 50-45 Ma (Wells et al., 2014). The tomographic vote maps at 524 depths shallower than $750 \mathrm{~km}$, show a new slab covering the "Southern Slab Gap" 525 (SSG in Fig. 11), and we interpret this as evidence for the consolidation of the c. 40 526 Ma trench (Fig. 11).

\subsection{Early Eocene changes in plate boundaries around North America: possible} causes and effects

530 It has been suggested that sudden changes in plate motions cannot be explained by fluid 531 dynamic convection models, but rather plate boundary forces that can change at shorter 532 timescales (Richards and Lithgow-Bertelloni, 1996). Several studies linked large 533 oceanic plateau subduction or obduction, slab break-off and continental tectonic 534 events like the Laramide orogeny phases in the western North America (e.g. Liu et al., 535 2010; Livaccari et al., 1981; Sigloch et al., 2008). Evolving plate boundary forces 536 associated with slab subduction and orogeny, or pressure-driven flow changes within 537 Earth's asthenosphere may be responsible for rapid plate motion variations 538 (Iaffaldano and Bunge, 2015). Bercovici et al., (2015) showed that the subduction of 539 thick oceanic lithosphere (oceanic plateaus) and associated grain-damage allow rapid 540 (in less than 1 million year) slab necking and detachment. This can account not only 541 for rapid upper plate uplift but also for precipitous changes in plate kinematics. 542 Following this line of thought, the arrival of the Siletzia LIP at the North American 
543 trench, and its subsequent subduction (Fig. 11), may have triggered the slab-breakoff

544 and marked the beginning of the slab gap observed in tomographic models of the

545 North American mantle (Fig. 11).

546 On the other hand, mantle upwelling linked to the slab window may have interacted

547 with the base of the North American plate and imposed a spin that led to changes in

548 relative plate motions. Zilio et al., (2017) quantified the drag exerted by subduction-

549 related mantle flow and concluded that basal-shear stresses, when integrated over

550 large plates, generate large tension forces that may exceed the strength of the

551 continental lithosphere, leading sometimes to breakup and opening distal basins. If

552 this is the case, then a peak in North American kimberlite occurrences is also

553 testifying for significant changes in Early Eocene intra-plate stresses due to mantle-

554 lithosphere interactions. It has been reported that the Cenozoic North American

555 kimberlites cluster around four main age groups: 59, 55, 53 and $47 \mathrm{Ma}$ (e.g. Creaser

556 R. A. et al., 2004; Graham I. et al., 1999). A statistical analysis of the North American

557 Eocene kimberlite data suggests two main kimberlite peaks: at 56 and $53 \mathrm{Ma}$

558 (Patterson and Francis, 2013). We observe that the peaks in kimberlite emplacement

559 ages coincide with Early Eocene changes at the North American plate boundaries (as

560 shown in section 3.2). We note however that the difficulties in establishing absolute

561 ages of kimberlites and associated uncertainties may alter some of the above-

562 mentioned results, but we consider that the entire span of Paleocene-Eocene

563 kimberlite ages which range from c. 59 to $47 \mathrm{Ma}$ (e.g. Tappe et al., 2018) is relevant

564 to our study. To explore the link between kimberlite eruption location and ages,

565 subducted slabs as imaged by tomographic images, and tentative reconstructions of

566 subducted slabs that may have carried remnants of Siletzia oceanic LIP, we show the

567 positions of two North American Eocene kimberlite clusters: one in Canada (with

568 ages spanning from 57.9 to $47.1 \mathrm{Ma}$ ), and one next to the Wyoming craton, just west

569 of accreted North American terranes, with ages from 51.5 to $47.8 \mathrm{Ma}$ ) in our

570 reconstructions presented in Fig. 11. A review of the two kimberlite groups can be

571 found in Patterson and Francis, (2013) and Tappe et al., (2018). We note that the

572 North American Eocene kimberlite emplacement is reconstructing on top slab gaps or

573 slab edges that may have facilitated the lower mantle to re-fertilize the depleted upper

574 convecting mantle with volatiles (Tappe et al., 2013). This gap was narrowing at 47

575 Ma and younger times (Fig. 11 and S3), and that may explain the lack of kimberlite

576 eruptions after $47 \mathrm{Ma}$. Vigorous mantle return flow due to subduction has been 
previously proposed as an emplacement mechanism for the anomalous Nd-Hf signature of the Eocene North American kimberlite (e.g. Tappe et al., 2013). More recently, Tappe et al., (2017) and Tappe et al., (2018) proposed that kimberlite magmatism can be tectonically controlled, for example when tensile stresses due to changing in plate motion are enhancing the success rate of evolving hybrid kimberlite magmas to reach Earth's surface.

583 We therefore suggest that the series of Eocene plate boundary alterations in the North

584 Atlantic realm were caused or amplified by changes in the dynamics of upper mantle under the North American plate triggered by oceanic LIP obduction, mid-ocean ridge subduction and slab break-off. Periodical mantle upwelling triggered by these events may have caused or enhanced fluctuations in North American plate seafloor spreading rates. However, we do not discard the role of the Iceland plume in the break-up and early seafloor spreading variations of the Northeast Atlantic that occurred prior to the postulated change in the subduction regime of the NE Pacific.

\section{Conclusions}

594 We have used a global database of magnetic anomaly and fracture identifications 595 supplemented with 3285 additional picks to construct a detailed model of oceanic 596 lithosphere age and seafloor spreading rates for the Eocene time. In particular, we aim 597 to map a series of tectonic events that occurred from 57 to $40 \mathrm{Ma}$ in the North 598 Atlantic and NE Pacific. We have revised evidence for changes in plate motion of the 599 North American plate relative to its neighbouring plates from the Arctic to the North 600 Atlantic, and in the NE Pacific. At least two periods of spreading rate increase 601 separated by sharp drops in these values are identified along the entire eastern North 602 American plate boundary from C25 to C18 time (c. 57 to $40 \mathrm{Ma}$ ). Changes in plate 603 motions at C25-24 time in the Labrador Sea coincide with the $2^{\text {nd }}$ phase of NAIP 604 volcanism and led to a surge in spreading rates in the entire North Atlantic. A sharp 605 decrease in spreading rate at C23 in the Labrador Sea and north of Charlie-Gibbs 606 fracture zone coincides with a clockwise motion of the subducting Farallon plate and 607 its possible fragmentation (see also Fig. S1) as well as the last phase of Cordilleran 608 terranes amalgamation to the North American craton. This change was likely due to 609 the collision and incipient subduction of the Siletzia volcanic plateau, a Large Igneous 610 Plateau which was formed on NE Pacific oceanic lithosphere at c. $56 \mathrm{Ma}$ (e.g. Wells 
611 et al., 2014). The collision of the North American trench with the thick volcanic 612 plateau diminished the western motion of the North American plate and caused the 613 seafloor-spreading drop in the North Atlantic. Subsequently, due to necking that 614 enabled grain-size reduction and rapid slab break-off (Bercovici et al., 2015), the 615 emergent upper mantle flow upwelling may have led to further variations in North 616 Atlantic spreading rates. Late Paleocene-Early Eocene kimberlite magmatism 617 documented in Canada and USA that erupted more than $1000 \mathrm{~km}$ away from the 618 Pacific plate boundary, constitute additional evidence for changes in the North 619 American plate mantle-lithosphere interactions in the Early Eocene.

620 This study aimed to present a series of Early Eocene tectonic events that occurred in 621 the same time on western and eastern part of the North America plate. We suggest 622 that these tectonic events separated by thousands of kilometres may be linked and 623 explained by lithosphere-mantle interactions triggered by subduction. However, a 624 proper understanding and testing causal links between plate motions and mantle 625 dynamics require an integrated approach that examines and analyses surface plate 626 motions, the distribution and geometry of slabs imaged by mantle tomography, and 627 models that employ state-of-the-art mantle convection modelling techniques.

\section{Acknowledgements}

630 The authors are grateful to Doug Wilson, Sebastian Tappe, an anonymous reviewer 631 and the Tectonophysics Editor-in-Chief Philippe Agard for their useful comments that 632 greatly improved our manuscript. C.G and J.J. acknowledge support from the 633 Research Council of Norway through its Centers of Excellence funding scheme, 634 project number 223272.

\section{REFERENCES}

Aitchison, J. C., Ali, J. R., and Davis, A. M., 2007, When and where did India and Asia collide?: Journal of Geophysical Research-Solid Earth, v. 112, no. B5.

Alvey, A., Gaina, C., Kusznir, N. J., and Torsvik, T. H., 2008, Integrated crustal thickness mapping and plate reconstructions for the high Arctic: Earth and Planetary Science Letters, v. 274, no. 3-4, p. 310-321.

Atwater, T., 1970, Implications of Plate Tectonics for the Cenozou Tectonic Evolution of Western North America: Geological Society of America Bulletin, v. 81, p. 35133536.

Atwater, T., and Menard, H. W., 1970, Magnetic lineations in the northeast Pacific: Earth and Planetary Sci. Letters, v. 7, p. 445-450. 
Bercovici, D., Shubert, G., and Ricard, Y., 2015, Abrupt tectonics and rapid slab detachment with grain-damage: Proceedings of the National Academy of Sciences of the United States of America, v. 112, no. 5.

Breitsprecher, K., Thorkelson, D. J., Groome, W. G., and Dostal, J., 2003, Geochemical confirmation of the Kula-Farallon slab window beneath the Pacific Northwest in Eocene time: Geology, v. 31, no. 4, p. 351-354.

Brozena, J. M., Childers, V. A., Lawver, L. A., Gahagan, L. M., Forsberg, R., Faleide, J. I., and Eldholm, O., 2003, New aerogeophysical study of the Eurasia Basin and Lomonosov Ridge: Implications for basin development: Geology, v. 31, no. 9, p. 825828.

Cande, S. C., Patriat, P., and Dyment, J., 2011, Motion between the Indian, Antarctic and African plates in the early Cenozoic (vol 183, pg 127, 2010): Geophysical Journal International, v. 185 , no. 1 , p. 574-574.

Cande, S. C., and Stegman, D. R., 2011, Indian and African plate motions driven by the push force of the Reunion plume head: Nature, v. 475, no. 7354, p. 47-52.

Caress, D. W., Menard, H. W., and Hey, R. N., 1988, Eocene reorganization of the PacificFarallon Spreading Center north of the Mendocino Fracture Zone: Journal of Geophysical Research, v. 93, p. 2813-2838.

Chalmers, J. A., Pulvertaft, T. C. R., Marcussen, C., and Pedersen, A. K., 1999, New insight into the structure of the Nuussuaq Basin, central West Greenland: Marine and Petroleum Geology, v. 16, no. 3, p. 197-224.

Cowan, D. S., 2003, Revisiting the Baranof-Leech River hypothesis for early Tertiary coastwise transport of the Chugach-Prince William terrane: Earth and Planetary Science Letters, v. 213, no. 3-4, p. 463-475.

Creaser R. A., Grütter, H., Carlson, J., and Crawford, B., 2004, Macrocrystal phlogopite Rb$\mathrm{Sr}$ dates for the Ekati property kimberlites, Slave Province, Canada: evidence for multiple intrusive episodes in the Paleocene and Eocene, : Lithos, v. 76, no. 1-4, p. 399-414.

Croon, M., Cande, S. C., and Stock, J. M., 2008, Revised Pacific-Antarctic plate motions and geophysics of the Menard Fracture Zone: Geochem. Geophys. Geosyst., v. 9, no. 7.

Davis, A. S., and Plafker, G., 1986, Eocene Basalts from the Yakutat Terrane - Evidence for the Origin of an Accreting Terrane in Southern Alaska: Geology, v. 14, no. 11, p. 963-966.

Domeier, M., Shephard, G. E., Jakob, J., Gaina, C., Doubrovine, P. V., and Torsvik, T. H., 2017, Intraoceanic subduction spanned the Pacific in the Late Cretaceous-Paleocene: Science Advances, v. 3, no. 11.

Dossing, A., Gaina, C., and Brozena, J. M., 2017, Building and breaking a large igneous province: An example from the High Arctic: Geophysical Research Letters, v. 44, no. 12, p. 6011-6019.

Dostal, J., Keppie, D. J., and Church, B. N., 2018, Generation of Eocene volcanic rocks from the Cordilleran arc of south-central British Columbia (Canada) during subduction of the Farallon and Resurrection plates and Yellowstone oceanic plateau: Geological Journal, p. 1-15.

Doubrovine, P. V., Steinberger, B., and Torsvik, T. H., 2012, Absolute plate motions in a reference frame defined by moving hot spots in the Pacific, Atlantic, and Indian oceans: Journal of Geophysical Research-Solid Earth, v. 117.

Duncan, R. A., 1982, A Captured Island Chain in the Coast Range of Oregon and Washington: Journal of Geophysical Research, v. 87, no. Nb13, p. 827-837.

Eddy, M. P., Clark, K. P., and Polenz, M., 2017, Age and volcanic stratigraphy of the Eocene Siletzia oceanic plateau in Washington and on Vancouver Island: Lithosphere, v. 9, no. 4 , p. 652-664.

Ehlers, B. M., and Jokat, W., 2009, Subsidence and crustal roughness of ultra-slow spreading ridges in the northern North Atlantic and the Arctic Ocean: Geophysical Journal International, v. 177, no. 2, p. 451-462. 
Enkin, R. J., 2006, Paleomagnetism and the case for Baja British Columbia in Haggart, J. W., Enkin, R. J., and Monger, J. W. H., eds., Paleogeography of the North American Cordillera: Evidence for and against Large-Scale Displacements, Volume 46, Geological Association of Canada p. 233-253.

Fouch, M. J., 2012, The Yellowstone Hotspot: Plume or Not?: Geology, v. 40, no. 5, p. 479480.

Gaina, C., Gernigon, L., and Ball, P., 2009, Paleocene-Recent Plate Boundaries in the NE Atlantic and the formation of Jan Mayen microcontinent: Journal of Geological Society London, v. 166, p. 601-616.

Gaina, C., Nasuti, A., Kimbell, G., and Blischke, A., 2017, Break-up and seafloor spreading domains in the NE Atlantic, in Peron-Pinvidic, G., Hopper, J. R., Stoker, M., Gaina, C., Doornebal, H., Funck, T., and Arting, U., eds., The Northeast Atlantic Region: A Reappraisal of Crustal Structure, Tectonostratigraphy and Magmatic Evolution, Volume 447: London, UK, Geological Society, London.

Gaina, C., Nikishin, A. M., and Petrov, E. I., 2015, Ultraslow spreading, ridge relocation and compressional events in the East Arctic region - A link to the Eurekan orogeny?: Arktos, v. 1, no. 1, p. 1-11.

Gaina, C., Roest, W. R., and Müller, R. D., 2002, Late Cretaceous-Cenozoic deformation of northeast Asia: Earth \& Planetary Science Letters, v. 197, p. 273-286.

Glebovsky, V. Y., Kaminsky, V. D., Minakov, A. N., Merkur'ev, S. A., Childers, V. A., and Brozena, J. M., 2006, Formation of the Eurasia Basin in the arctic ocean as inferred from geohistorical analysis of the anomalous magnetic: Geotectonics, v. 40, no. 4, p. 263-281.

Goes, S., Agrusta, R., van Hunen, J., and Garel, F., 2017, Subduction-transition zone interaction: A review: Geosphere, v. 13, no. 3, p. 644-664.

Graham I., Burgess, J. L., Bryan, D., Ravenscroft, P. J., Thomas, E., Doyle, B. J., Hopkings, R., and Armstrong, K. A., 1999, Exploration history and geology of the Diavik kimberlites, Lac de Gras, Northwest Territories, Canada, Seventh International Kimberlite Conference, Volume 1, p. 262-279.

Haeussler, P. J., Bradley, D. C., Wells, R. E., and Miller, M. L., 2003, Life and death of the Resurrection plate: Evidence for its existence and subduction in the northeastern Pacific in Paleocene-Eocene time: Geological Society of America Bulletin, v. 115, no. 7, p. 867-880.

Iaffaldano, G., Davies, D. R., and DeMets, C., 2018, Indian Ocean floor deformation induced by the Reunion plume rather than the Tibetan Plateau: Nature Geoscience, v. 11, no. 5, p. 362-+.

Johnston, S. T., and Thorkelson, D. J., 2000, Continental flood basalts: Episodic magmatism above long-lived hotspots Earth and Planetary Science Letters, v. 175, p. 247-256.

Kristoffersen, Y., 1978, Sea-floor spreading and the early opening of the North Atlantic: Earth and Planetary Science Letters, v. 38, p. 273-290.

Labails, C., Olivet, J. L., Aslanian, D., and Roest, W. R., 2010, An alternative early opening scenario for the Central Atlantic Ocean: Earth and Planetary Science Letters, v. 297, no. 3-4, p. 355-368.

Liu, L. J., Gurnis, M., Seton, M., Saleeby, J., Muller, R. D., and Jackson, J. M., 2010, The role of oceanic plateau subduction in the Laramide orogeny: Nature Geoscience, v. 3, no. 5 , p. 353-357.

Livaccari, R. F., Burke, K., and Sengor, A. M. C., 1981, Was the Laramide orogeny related to subduction of an oceanic plateau?: Nature, v. 289, no. 5795, p. 276-278.

Lonsdale, P., 1988, Paleogene history of the Kula plate: Offshore evidence and onshore implications: Geological Society American Bulletin, v. 733-754, p. 733-754.

Louden, K. E., Tucholke, B. E., and Oakey, G. N., 2004, Regional anomalies of sediment thickness, basement depth and isostatic crustal thickness in the North Atlantic Ocean: Earth and Planetary Science Letters, v. 224, no. 1-2, p. 193-211.

Luis, J. F., and Miranda, J. M., 2008, Reevaluation of magnetic chrons in the North Atlantic between 35 degrees $\mathrm{N}$ and 47 degrees $\mathrm{N}$ : Implications for the formation of the Azores 
Triple Junction and associated plateau: Journal of Geophysical Research-Solid Earth, v. 113 , no. B10.

Madsen, J. K., Thorkelson, D. J., Friedman, R. M., and Marshall, D. D., 2006, Cenozoic to Recent plate configurations in the Pacific Basin: Ridge subduction and slab window magmatism in western North America: Geosphere, v. 2, no. 1, p. 11-34.

Matthews, K. J., Muller, R. D., Wessel, P., and Whittaker, J. M., 2011, The tectonic fabric of the ocean basins: Journal of Geophysical Research-Solid Earth, v. 116.

McCrory, P. A., and Wilson, D. S., 2013, A kinematic model for the formation of the SiletzCrescent forearc terrane by capture of coherent fragments of the Farallon and Resurrection plates: Tectonics, v. 32, no. 3, p. 718-736.

McCrory, P. A., Wilson, D. S., and Stanley, R. G., 2009, Continuing evolution of the PacificJuan de Fuca-North America slab window system-A trench-ridge-transform example from the Pacific Rim: Tectonophysics, v. 464, no. 1-4, p. 30-42.

Menard, H. W., 1978, Fragmentation of the Farallon plate by pivoting subduction: Journal of Geology, v. 86, p. 99-110.

Meyer, B., Saltus, R., and Chulliat, A., 2017, EMAG2: Earth Magnetic Anomaly Grid (2-arcminute resolution) Version 3, in National Centers for Environmental Information, N., ed., National Centers for Environmental Information, NOAA.

Müller, R. D., Cande, S. C., Royer, J.-Y., Roest, W. R., and Maschenkov, S., 1999, New constraints on the Late Cretaceous/Tertiary plate tectonic evolution of the Caribbean, in Mann, P., ed., Caribbean Basins, Volume 4: Amsterdam, Elsevier, p. 39-55.

Müller, R. D., and Roest, W. R., 1992, Fracture zones in the North Atlantic from combined Geosat and Seasat data: Journal of Geophysical Research, v. 97, no. B3, p. 33373350.

Müller, R. D., Sdrolias, M., Gaina, C., and Roest, W. R., 2008, Age, spreading rates, and spreading asymmetry of the world's ocean crust: Geochemistry Geophysics Geosystems, v. 9.

Muller, R. D., Seton, M., Zahirovic, S., Williams, S. E., Matthews, K. J., Wright, N. M., Shephard, G. E., Maloney, K. T., Barnett-Moore, N., Hosseinpour, M., Bower, D. J., and Cannon, J., 2016, Ocean Basin Evolution and Global-Scale Plate Reorganization Events Since Pangea Breakup: Annual Review of Earth and Planetary Sciences, Vol 44, v. 44, p. 107-138.

Najman, Y., Jenks, D., Godin, L., Boudagher-Fadel, M., Millar, I., Garzanti, E., Horstwood, M., and Bracciali, L., 2017, The Tethyan Himalayan detrital record shows that IndiaAsia terminal collision occurred by $54 \mathrm{Ma}$ in the Western Himalaya: Earth and Planetary Science Letters, v. 459, p. 301-310.

Nirrengarten, M., Manatschal, G., Tugend, J., Kusznir, N. J., and Sauter, D., 2017, Nature and origin of the J-magnetic anomaly offshore Iberia-Newfoundland: implications for plate reconstructions: Terra Nova, v. 29, no. 1, p. 20-28.

Oakey, G. N., and Chalmers, J. A., 2012, A new model for the Paleogene motion of Greenland relative to North America: Plate reconstructions of the Davis Strait and Nares Strait regions between Canada and Greenland: Journal of Geophysical Research-Solid Earth, v. 117.

Ogg, J. G., 2012, The Geomagnetic Polarity Timescale, in Gradstein, F. M., Ogg, J. G., Schmitz, M., and Ogg, G., eds., The Geologic Time Scale 2012, Volume 2: Amsterdam, Elsevier, p. 85-115.

Patriat, P., and Achache, J., 1984, India-Eurasia collision chronology has implications for crustal shortening and driving mechanisms of plates: Nature, v. 311, p. 615-621.

Patterson, M. V., and Francis, D., 2013, Kimberlite eruptions as triggers for early Cenozoic hyperthermals: Geochem. Geophys. Geosyst., v. 14, no. 2.

Pavlis, G. L., Sigloch, K., Burdick, S., Fouch, M. J., and Vernon, F. L., 2012, Unraveling the geometry of the Farallon plate: Synthesis of three-dimensional imaging results from USArray: Tectonophysics, v. 532, p. 82-102. 
Peron-Pinvidic, G., and Manatschal, G., 2009, The final rifting evolution at deep magma-poor passive margins from Iberia-Newfoundland: a new point of view: International Journal of Earth Sciences, v. 98, no. 7, p. 1581-1597.

Petronotis, K. E., Gordon, R. G., and Acton, G. D., 1994, A 57 Ma Pacific Plate Paleomagnetic Pole Determined from a Skewness Analysis of Crossings of Marine Magnetic Anomaly 25r: Geophysical Journal International, v. 118, no. 3, p. 529-554.

Phillips, B. A., Kerr, A. C., Mullen, E. K., and Weis, D., 2017, Oceanic mafic magmatism in the Siletz terrane, NW North America: Fragments of an Eocene oceanic plateau?: Lithos, v. 274, p. 291-303.

Piepjohn, K., von Gosen, W., and Tessensohn, F., 2016, The Eurekan deformation in the Arctic: an outline: Journal of the Geological Society, v. 173, no. 6, p. 1007-1024.

Pitman, W. C., III, and Talwani, M., 1972, Seafloor spreading in the North Atlantic: Geological Society of America Bulletin, v. 83, p. 619-646.

Richards, M. A., and Lithgow-Bertelloni, C., 1996, Plate motion changes, the HawaiianEmperor bend, and the apparent success and failure of geodynamic models: Earth and Planetary Science Letters, v. 137, no. 1-4, p. 19-27.

Roest, W. R., and Srivastava, S. P., 1989, Sea-Floor Spreading in the Labrador Sea - a New Reconstruction: Geology, v. 17, no. 11, p. 1000-1003.

-, 1991, Kinematics of the Plate Boundaries between Eurasia, Iberia, and Africa in the NorthAtlantic from the Late Cretaceous to the Present: Geology, v. 19, no. 6, p. 613-616.

Rona, P. A., and Richardson, E. S., 1978, Early Cenozoic Global Plate Reorganization: Earth and Planetary Science Letters, v. 40, no. 1, p. 1-11.

Rosa, J. W. C., and Molnar, P., 1988, Uncertainties in reconstructions of the Pacific, Farallon, Vancouver and Kula plates and constrains on the rigidity of the Pacific and Farallon (and Vancouver) plates between 72 and $35 \mathrm{Ma}$ : Journal of Geophysical Research, v. 93, no. B4, p. 2997-3008.

Ryan, W. B. F., Carbotte, S. M., Coplan, J. O., O’Hara, S., Melkonian, A., Arko, R., Weissel, R. A., Vicki Ferrini, V., Goodwillie, A., Nitsche, F., Bonczkowski, J., and Zemsky, R., 2009, Global Multi-Resolution Topography synthesis: Geochemistry, Geophysics, Geosystems, v. 10, no. 3.

Sandwell, D. T., Muller, R. D., Smith, W. H. F., Garcia, E., and Francis, R., 2014, New global marine gravity model from CryoSat-2 and Jason-1 reveals buried tectonic structure: Science, v. 346, no. 6205, p. 65-67.

Saunders, A. D., Jones, S. M., Morgan, L. A., Pierce, K. L., Widdowson, M., and Xu, Y. G., 2007, Regional uplift associated with continental large igneous provinces: The roles of mantle plumes and the lithosphere: Chemical Geology, v. 241, no. 3-4, p. 282-318.

Seton, M., Flament, N., Whittaker, J., Muller, R. D., Gurnis, M., and Bower, D. J., 2015, Ridge subduction sparked reorganization of the Pacific plate-mantle system 60-50 million years ago: Geophysical Research Letters, v. 42, no. 6, p. 1732-1740.

Seton, M., Müller, R. D., Zahirovic, S., Gaina, C., Torsvik, T., Shephard, G., Talsma, A., Gurnis, M., Turner, M., Maus, S., and Chandler, M., 2012, Global continental and ocean basin reconstructions since 200Ma: Earth-Science Reviews, v. 113, no. 3-4, p. 212-270.

Seton, M., Whittaker, J. M., Wessel, P., Muller, R. D., DeMets, C., Merkouriev, S., Cande, S., Gaina, C., Eagles, G., Granot, R., Stock, J., Wright, N., and Williams, S. E., 2014, Community infrastructure and repository for marine magnetic identifications: Geochemistry Geophysics Geosystems, v. 15, no. 4, p. 1629-1641.

Sharp, W. D., and Clague, D. A., 2006, 50-Ma initiation of Hawaiian-Emperor bend records major change in Pacific plate motion: Science, v. 313, no. 5791, p. 1281-1284.

Shephard, G. E., Matthews, K. J., Hosseini, K., and Domeier, M., 2017, On the consistency of seismically imaged lower mantle slabs: Scientific Reports, v. 7.

Sigloch, K., 2011, Mantle provinces under North America from multifrequency P wave tomography: Geochemistry Geophysics Geosystems, v. 12. 
Sigloch, K., Mcquarrie, N., and Nolet, G., 2008, Two-stage subduction history under North America inferred from multiple-frequency tomography: Nature Geoscience, v. 1, no. 7, p. 458-462.

Sigloch, K., and Mihalynuk, M. G., 2013, Intra-oceanic subduction shaped the assembly of Cordilleran North America: Nature, v. 496, no. 7443, p. 50-+.

Srivastava, S. P., and Tapscott, C. R., 1986, Plate kinematics of the North Atlantic, in R., V. P., and Tucholke, B. E., eds., The Western North Atlantic Region, Volume M, Geol. Soc. Am., p. 379-405.

Stegman, D. R., Farrington, R., Capitanio, F. A., and Schellart, W. P., 2010, A regime diagram for subduction styles from 3-D numerical models of free subduction: Tectonophysics, v. 483, no. 1-2, p. 29-45.

Stock, J., and Molnar, P., 1988, Uncertainties and Implications of the Late Cretaceous and Tertiary Position of North-America Relative to the Farallon, Kula, and Pacific Plates: Tectonics, v. 7, no. 6, p. 1339-1384.

Storey, M., Duncan, R. A., and Tegner, C., 2007, Timing and duration of volcanism in the North Atlantic Igneous Province: Implications for geodynamics and links to the Iceland hotspot: Chemical Geology, v. 241, no. 3-4, p. 264-281.

Tappe, S., Smart, K., Torsvik, T., Massuyeau, M., and de Wit, M., 2018, Geodynamics of kimberlites on a cooling Earth: Clues to plate tectonic evolution and deep volatile cycles: Earth and Planetary Science Letters, v. 484, p. 1-14.

Torsvik, T. H., Doubrovine, P., Steinberger, B., Gaina, C., Spakman, W., and Domeier, M., 2017, Pacific plate motion change caused the Hawaiian-Emperor Bend: Nature Communications.

Tucholke, B. E. a. S., H., 1988, Kane Fracture Zone: Marine Geophys. Res., v. 10, p. 1-39.

van Hinsbergen, D. J. J., Steinberger, B., Doubrovine, P. V., and Gassmöller, R., 2011, Acceleration and deceleration of India-Asia convergence since the Cretaceous: Roles of mantle plumes and continental collision: Journal of Geophysical Research.

Verhoef, J., Roest, W. R., Macnab, R., and Arkani, H. J., 1996, Magnetic anomalies of the Arctic and North Atlantic oceans and adjacent areas: Ottawa, Geological Survey of Canada, p. CD compilation.

Wells, R., Bukry, D., Friedman, R., Pyle, D., Duncan, R., Haeussler, P., and Wooden, J., 2014, Geologic history of Siletzia, a large igneous province in the Oregon and Washington Coast Range: Correlation to the geomagnetic polarity time scale and implications for a long-lived Yellowstone hotspot: Geosphere, v. 10, no. 4, p. 692719.

Wells, R. E., Engebretson, D. C., Snavely, P. D., and Coe, R. S., 1984, Cenozoic plate motions and the volcanotectonic evolution of western Oregon and Washington: Tectonics, v. 3, p. 274-294.

White, R. S., 1992, Crustal Structure and Magmatism of North-Atlantic Continental Margins: Journal of the Geological Society, v. 149, p. 841-854.

Whittaker, J. M., Muller, R. D., Leitchenkov, G., Stagg, H., Sdrolias, M., Gaina, C., and Goncharov, A., 2007, Major Australian-Antarctic plate reorganization at HawaiianEmperor bend time: Science, v. 318, no. 5847, p. 83-86.

Wright, N. M., Muller, R. D., Seton, M., and Williams, S. E., 2015, Revision of Paleogene plate motions in the Pacific and implications for the Hawaiian-Emperor bend: Geology, v. 43, no. 5, p. 455-458.

Zilio, L. D., Faccenda, M., and Capitanio, F., 2017, The role of deep subduction in supercontinent breakup: Tectonophysics. 
912 Table 1. Magnetic anomaly identifications (* "o" and "y" stand for "old" and "young" 913 sides of normal (n) reverse (r) magnetised oceanic crust)

\begin{tabular}{|c|c|c|}
\hline Chron* & $\begin{array}{l}\text { Age [Ma] } \\
\text { Cande\&Kent } \\
(1995)\end{array}$ & $\begin{array}{l}\text { Age [Ma] } \\
\quad 915 \\
\text { Ogg } \\
(2012916\end{array}$ \\
\hline 13ny & 33.058 & 33.15917 \\
\hline 18n.1ny & 38.426 & 38.834 918 \\
\hline $18 \mathrm{n} .2 \mathrm{no}$ & 40.130 & $\begin{array}{r}919 \\
\mathbf{4 0 . 3 2 1}\end{array}$ \\
\hline 20ny & 42.536 & $\begin{array}{r}920 \\
42.301 \\
921\end{array}$ \\
\hline $20 \mathrm{no}$ & 43.789 & 43.43922 \\
\hline 21 ny & 46.264 & 45.689)23 \\
\hline $21 \mathrm{no}$ & 47.906 & 47.32924 \\
\hline 22 no & 49.714 & $49.335^{25}$ \\
\hline 23n.1ny & 50.778 & $\begin{array}{r}926 \\
\mathbf{5 0 . 6 1 3}\end{array}$ \\
\hline $23 \mathrm{n} .2 \mathrm{no}$ & 51.743 & $\mathbf{5 1 . 8 2 6} 928$ \\
\hline 24n.1ny & 52.364 & 52.62929 \\
\hline 24n.3no & 53.347 & 53.939) 30 \\
\hline 25ny & 56.904 & $\mathbf{5 7 . 1 0 9 3 1}$ \\
\hline 26 no & 57.911 & $\mathbf{5 9 . 1} 932$ \\
\hline 27 ny & 60.92 & $\mathbf{6 2 . 2 2}^{933}$ \\
\hline 28 ny & 62.499 & $\begin{array}{r}934 \\
63.49 \\
\end{array}$ \\
\hline 30ny & 65.578 & $\begin{array}{r}935 \\
66.398 \\
36\end{array}$ \\
\hline
\end{tabular}

937

938 

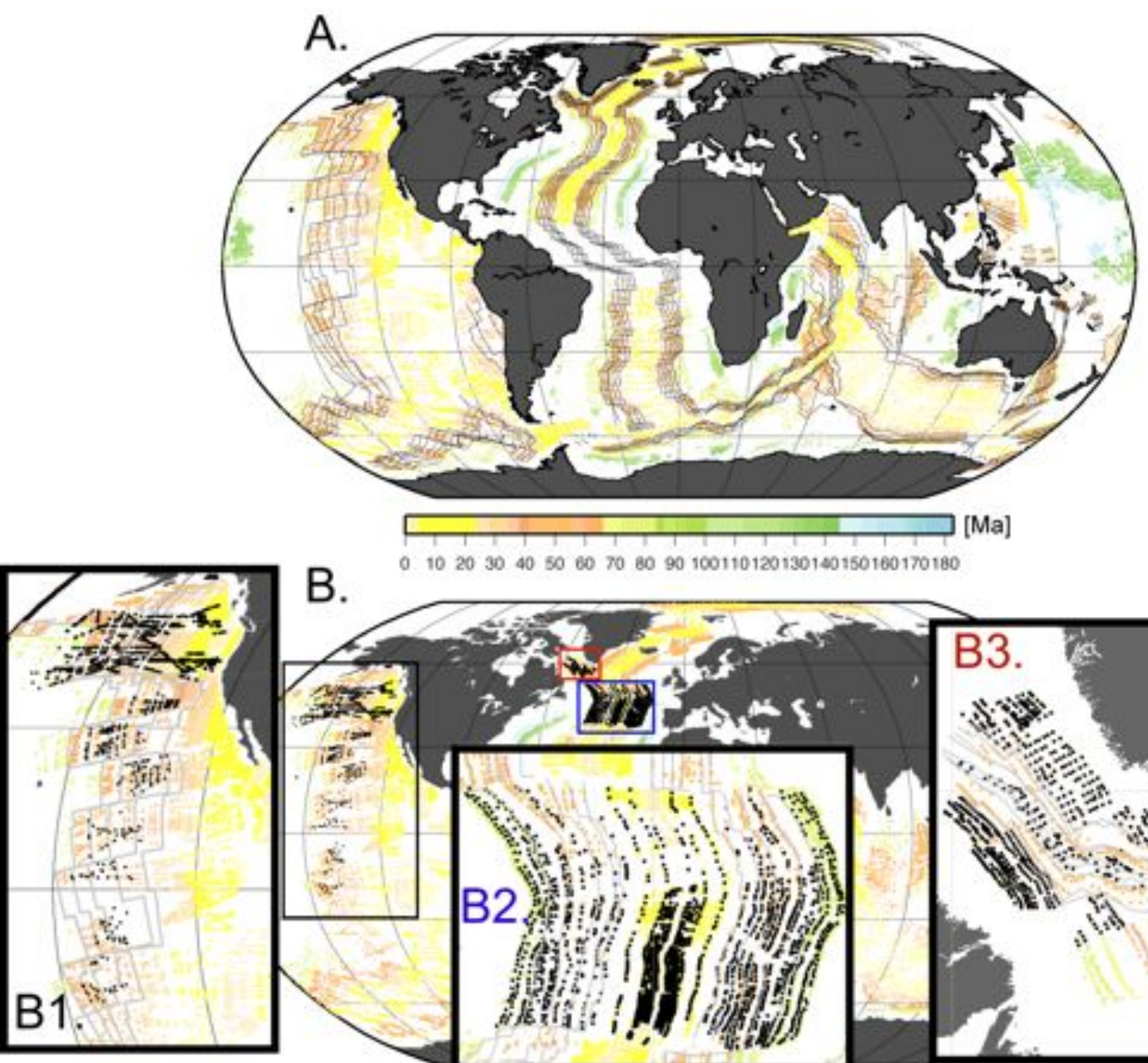

B.

$0.102030 \quad 40506070 \quad 8090100110120130140150160170180$

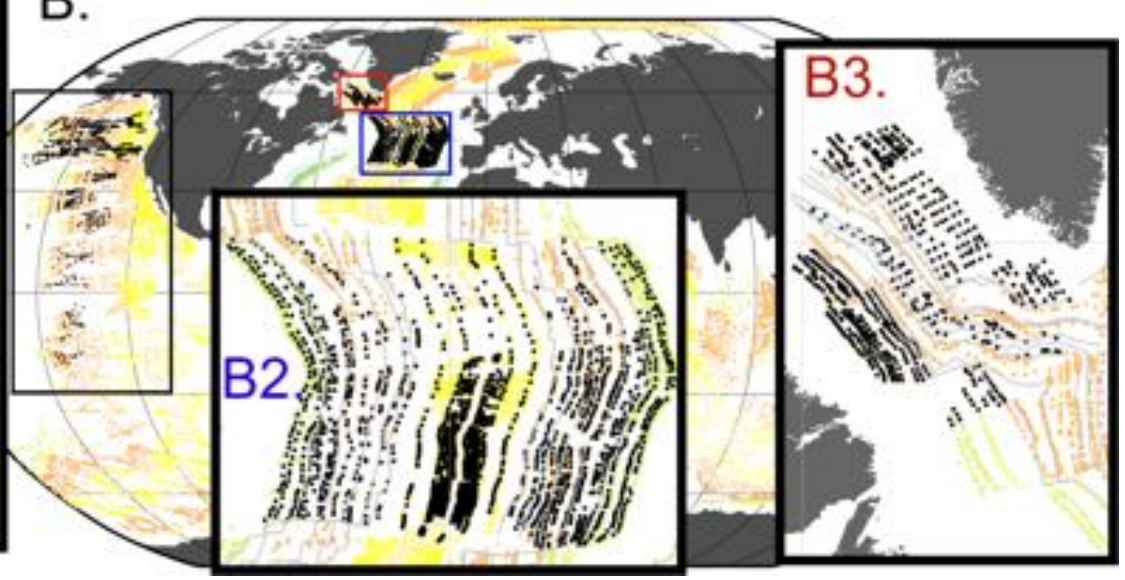

941 Fig.1. Global database of magnetic anomaly picks (Seton et al., 2014)(coloured dots),

942 global Paleocen-Eocene (67.7, 55.9, 47.9, 40.1 and 33.1 Ma (Müller et al., 2016)

943 isochrons (black thin lines). Panel B shows the location of additional datasets of

944 magnetic anomaly picks used in this study (B1 - NE Pacific, B2 - North Atlantic and 945 B3 - Labrador Sea, see text for details). 

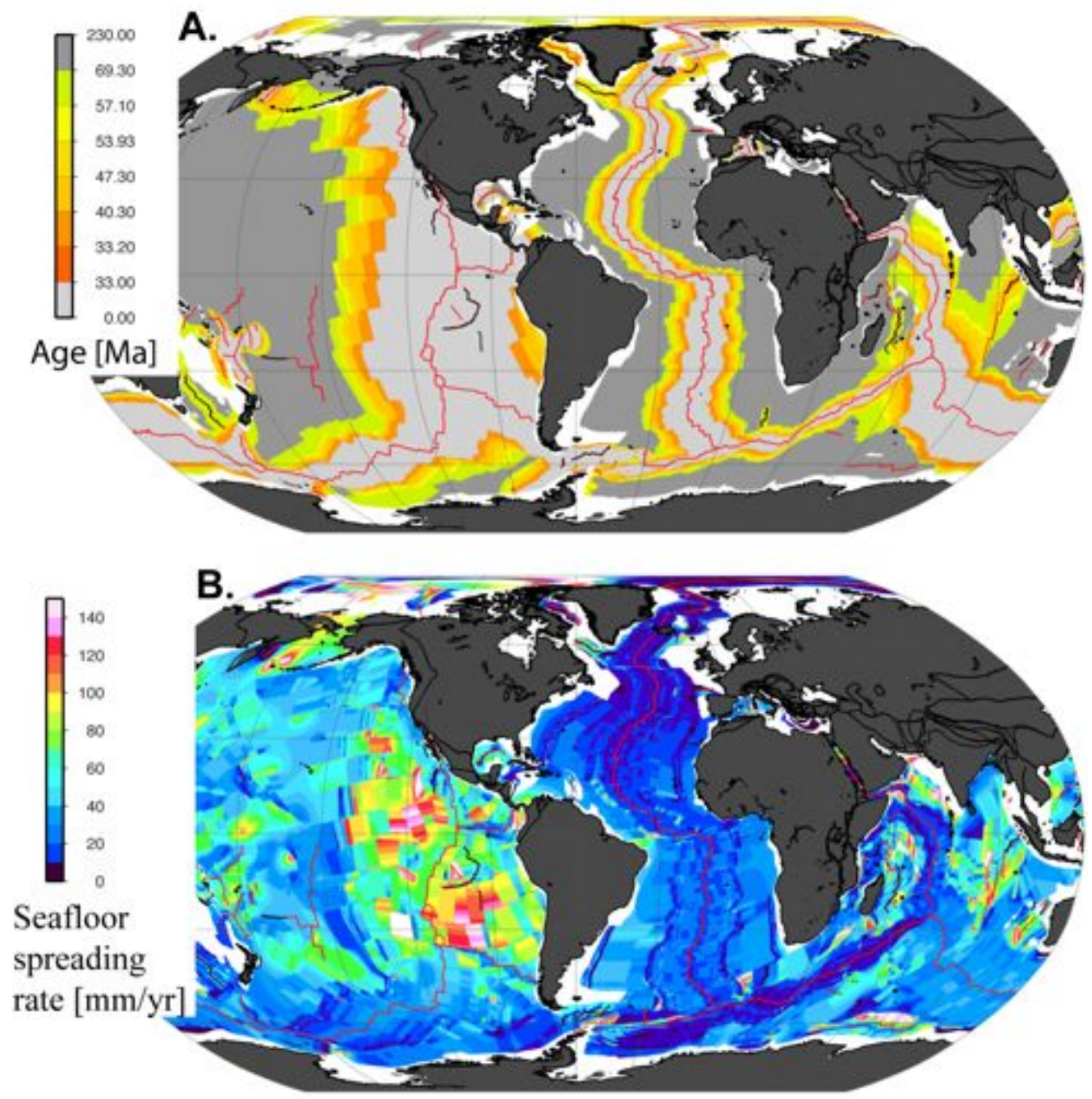

949

Fig. 2. A. Global oceanic lithosphere age-grid (here shown only the newly951 constructed Eocene part), and B. Global half seafloor-spreading rates. 

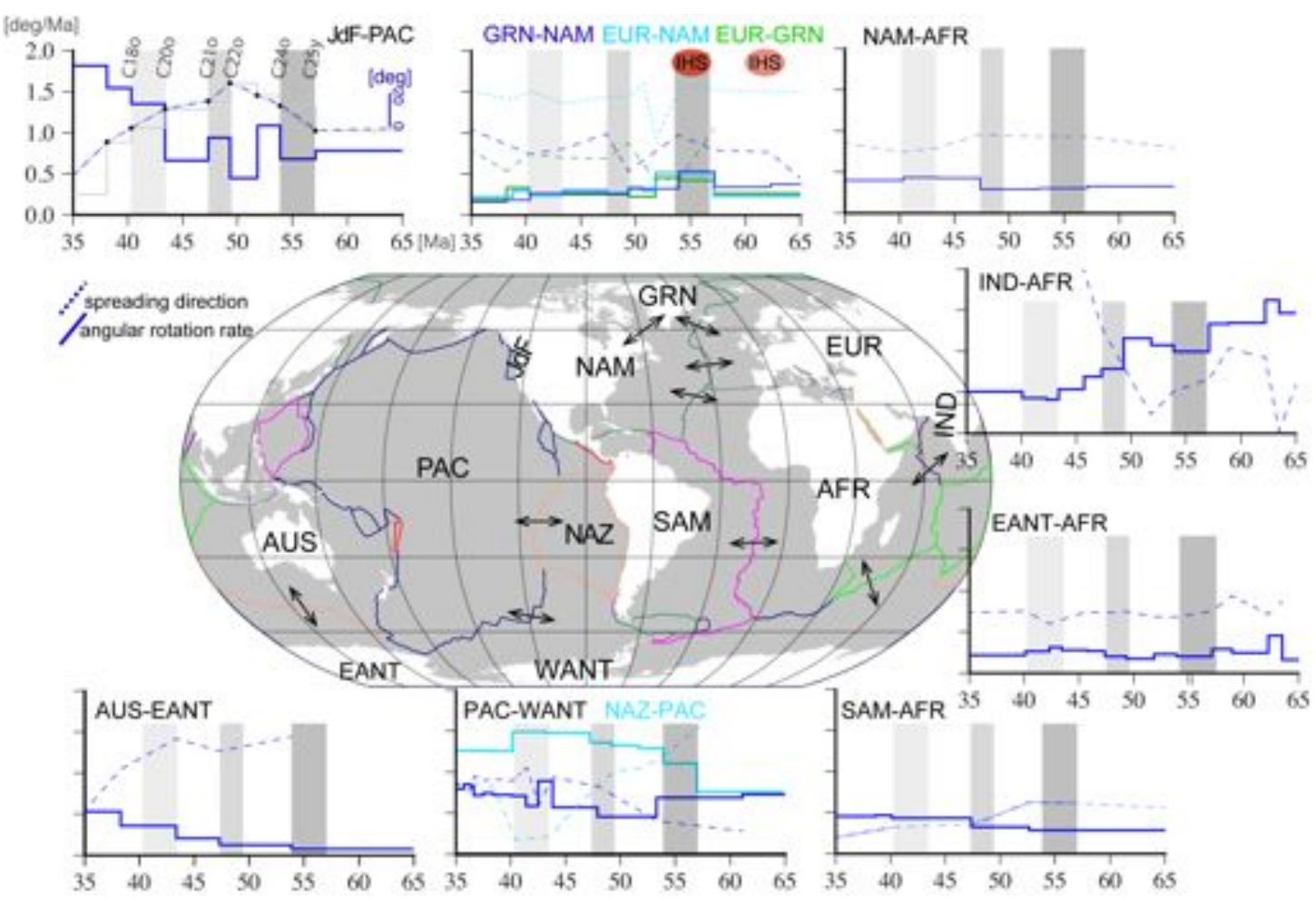

956 Fig. 3. Snapshots of changes in relative plate motions at $\mathrm{C} 25-\mathrm{C} 17$ time in major oceanic basins. Blue lines indicate angular rotation rates (in degrees per million years). Dashed lines shows spreading directions (in degrees), values calculated at the 959 end of each rotation stage (see upper left panel as an example, also Fig. S2). Present960 day position of mid-ocean ridge points which were reconstructed in time for 961 calculating seafloor spreading parameters are indicated by the intersection of black 962 arrows and selected mid-ocean ridges. Stage rotations and references used for these 963 calculations are shown in Table S2. Various grey-shaded rectangles show the extent 964 of chron intervals: $\mathrm{C} 25 \mathrm{y}-24 \mathrm{o}, \mathrm{C} 22 \mathrm{o}-\mathrm{C} 21 \mathrm{o}$, and $\mathrm{C} 20 \mathrm{o}-\mathrm{C} 18 \mathrm{o}$ respectively. 965 Abbreviations: AFR-Africa, AUS-Australia, EANT-East Antarctica, EUR-Eurasia, 966 GRN-Greenland, JdF-Juan de Fuca, IHS-Iceland Hotspot, IND-India, NAM-North 967 America, NAZ-Nazca, PAC-Pacific, SAM-South America, WANT-West Antarctica. 

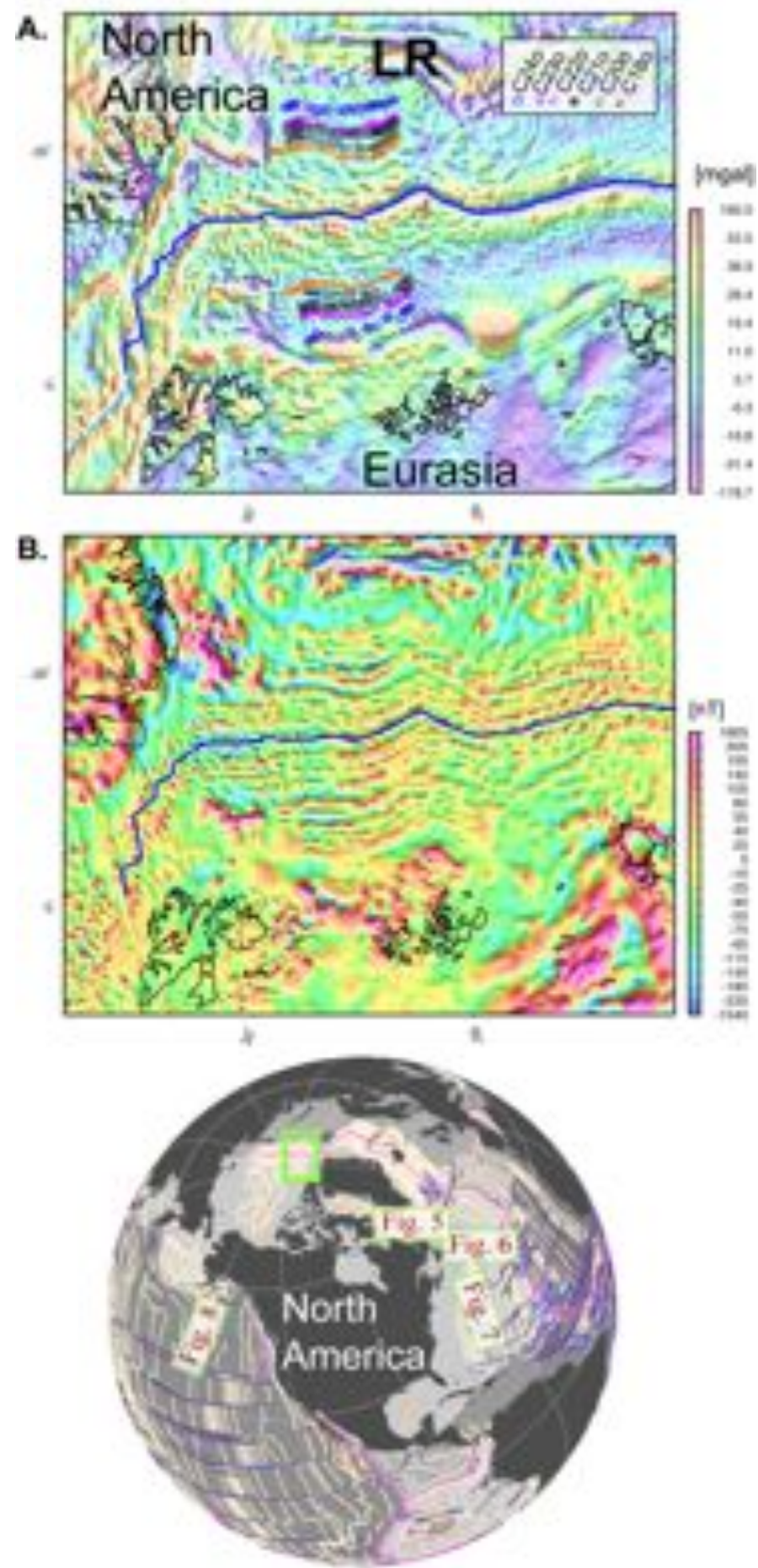

971 Fig. 4. A. Magnetic anomaly grid (Gaina et al., 2011) and B. Free air gravity anomaly

972 derived from satellite altimetry (Sandwell et al., 2014) for the Eurasia Basin (see

973 location on the globe). Various symbols show the distribution of magnetic anomaly

974 picks used to derive the regional isochron model. Thin blue line is the active mid975 ocean ridge. LR stands for Lomonosov Ridge. 
A.

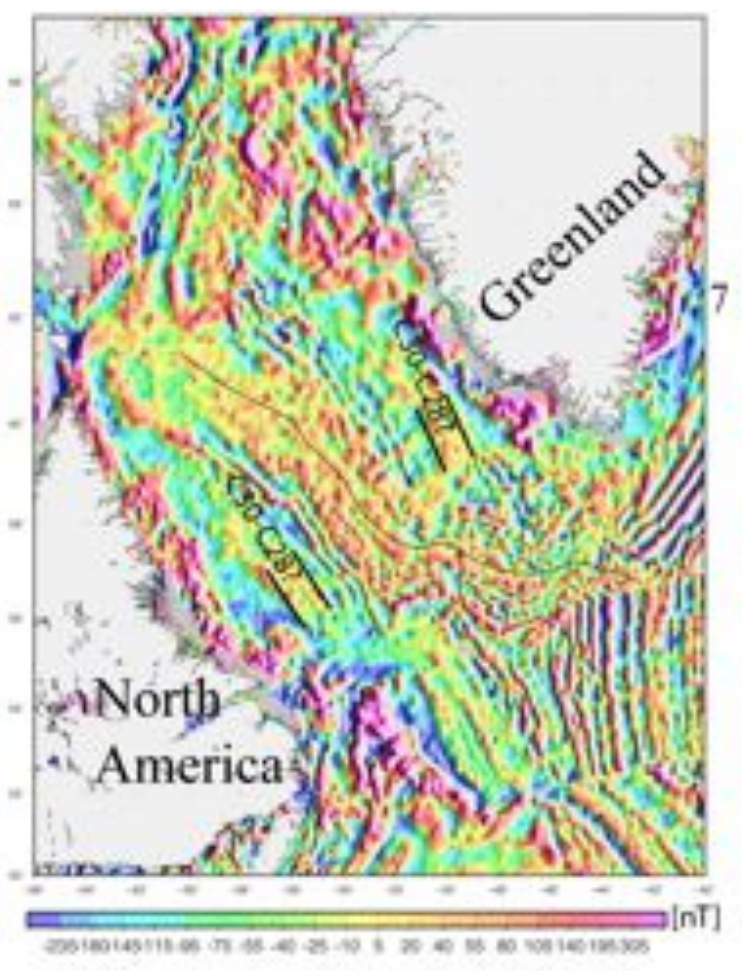

B.

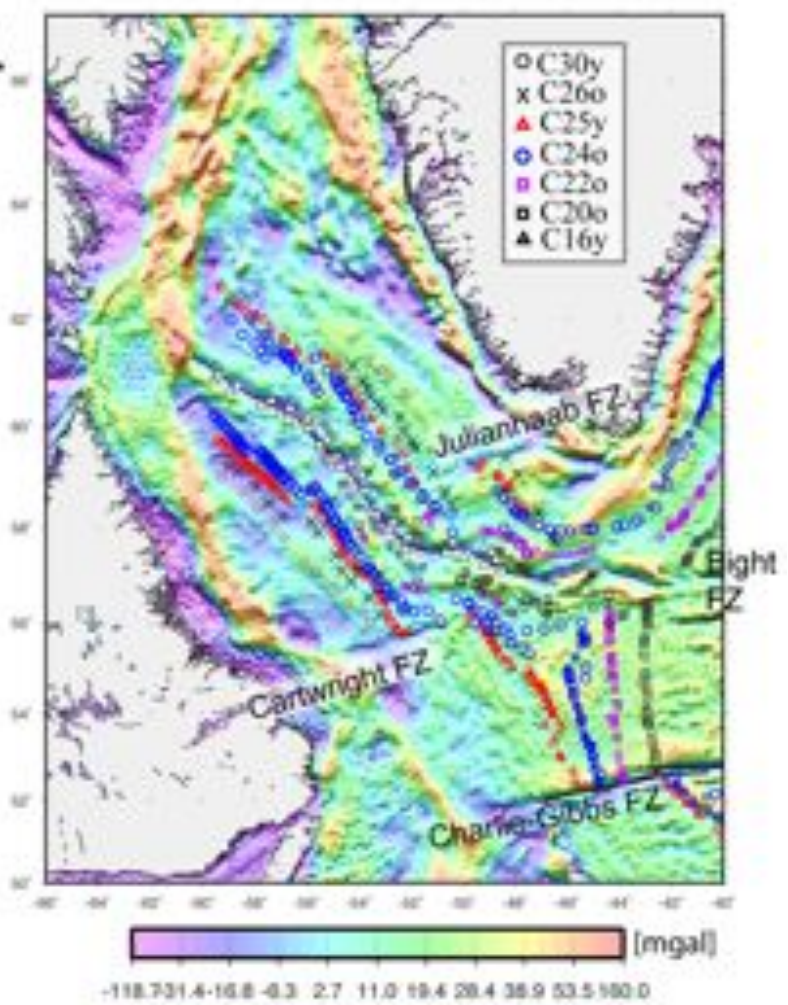

Fig. 5. A. Magnetic anomaly grid (Verhoef et al., 1996) and B. Free air gravity anomaly derived from satellite altimetry (Sandwell et al., 2014) for the Labrador Sea 981 (see location in Fig. 4). Various symbols show the distribution of magnetic anomaly 982 picks used to derive the regional isochron model. Thin black line is the extinct mid983 ocean ridge. FZ stands for "fracture zone". 

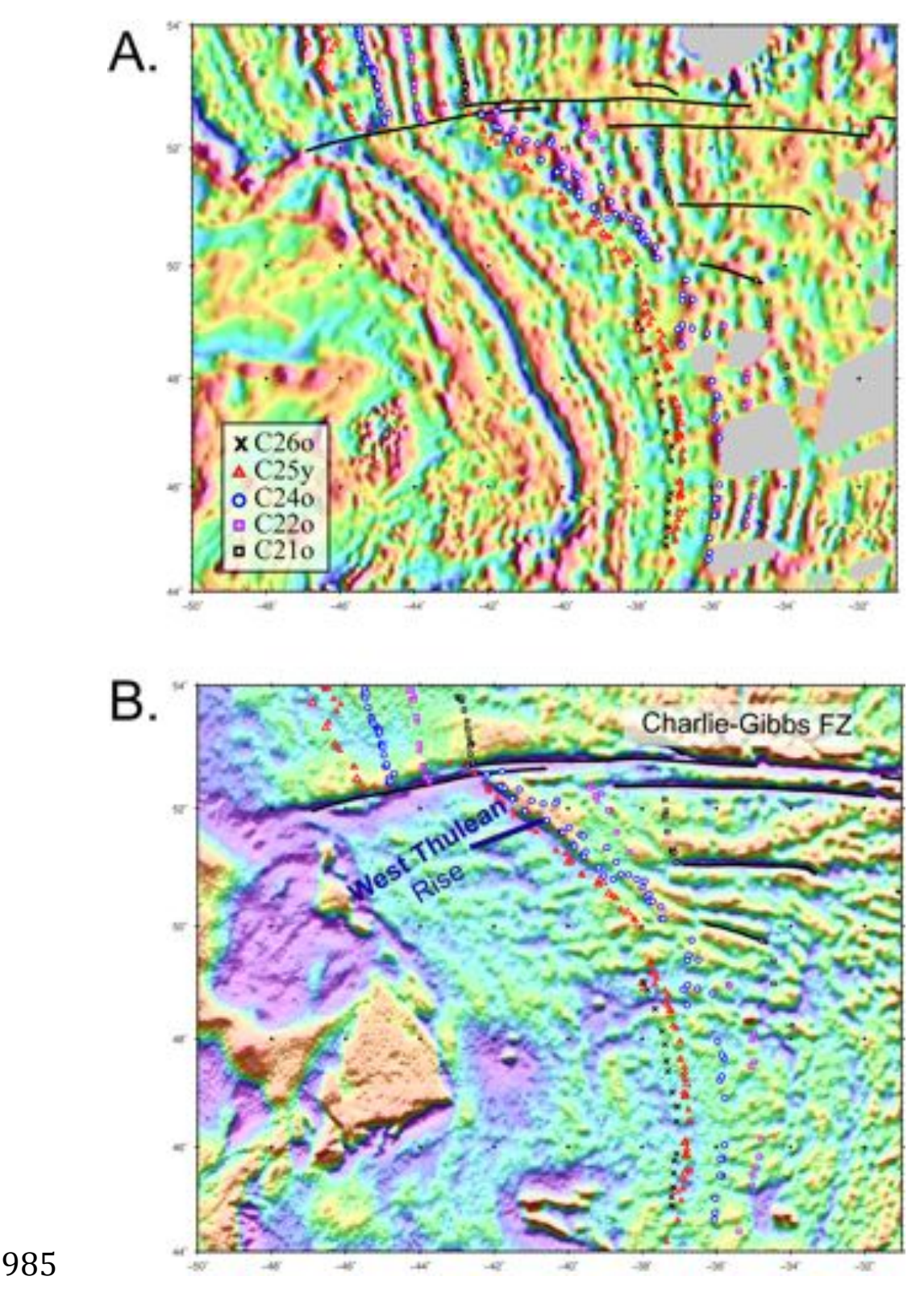

986 Fig. 6. A. Magnetic anomaly grid (Verhoef et al., 1996) and B. Free air gravity 987 anomaly derived from satellite altimetry (Sandwell et al., 2014) for North Atlantic 988 the North American side south of Charlie-Gibbs fracture zone (see location in Fig. 4). 989 Various symbols show the distribution of magnetic anomaly picks used to derive the 990 regional isochron model. Black lines are fracture zone identifications (Matthews et 991 al., 2011). 

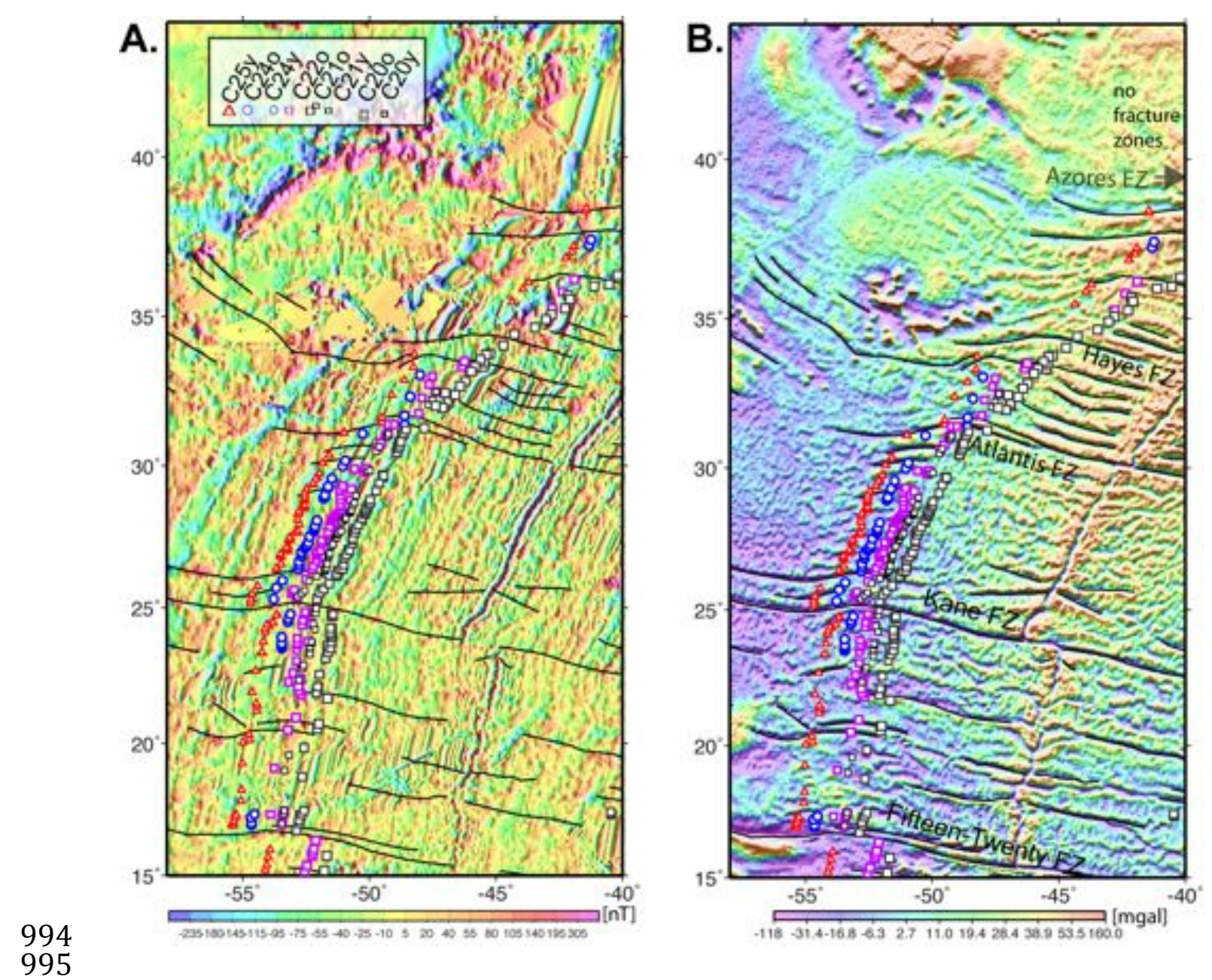

996 Fig. 7. A. Magnetic anomaly grid (Meyer et al., 2017), and B. Free air gravity 997 anomaly derived from satellite altimetry (Sandwell et al., 2014) for North Atlantic 998 the North American side, south of the Azores and north of Fifteen-Twenty fracture 999 zone (see location in Fig. 4). Various symbols show the distribution of magnetic 1000 anomaly picks used to derive the regional isochron model. Black lines are fracture 1001 zone identifications (Matthews et al., 2011).

1002 1003 

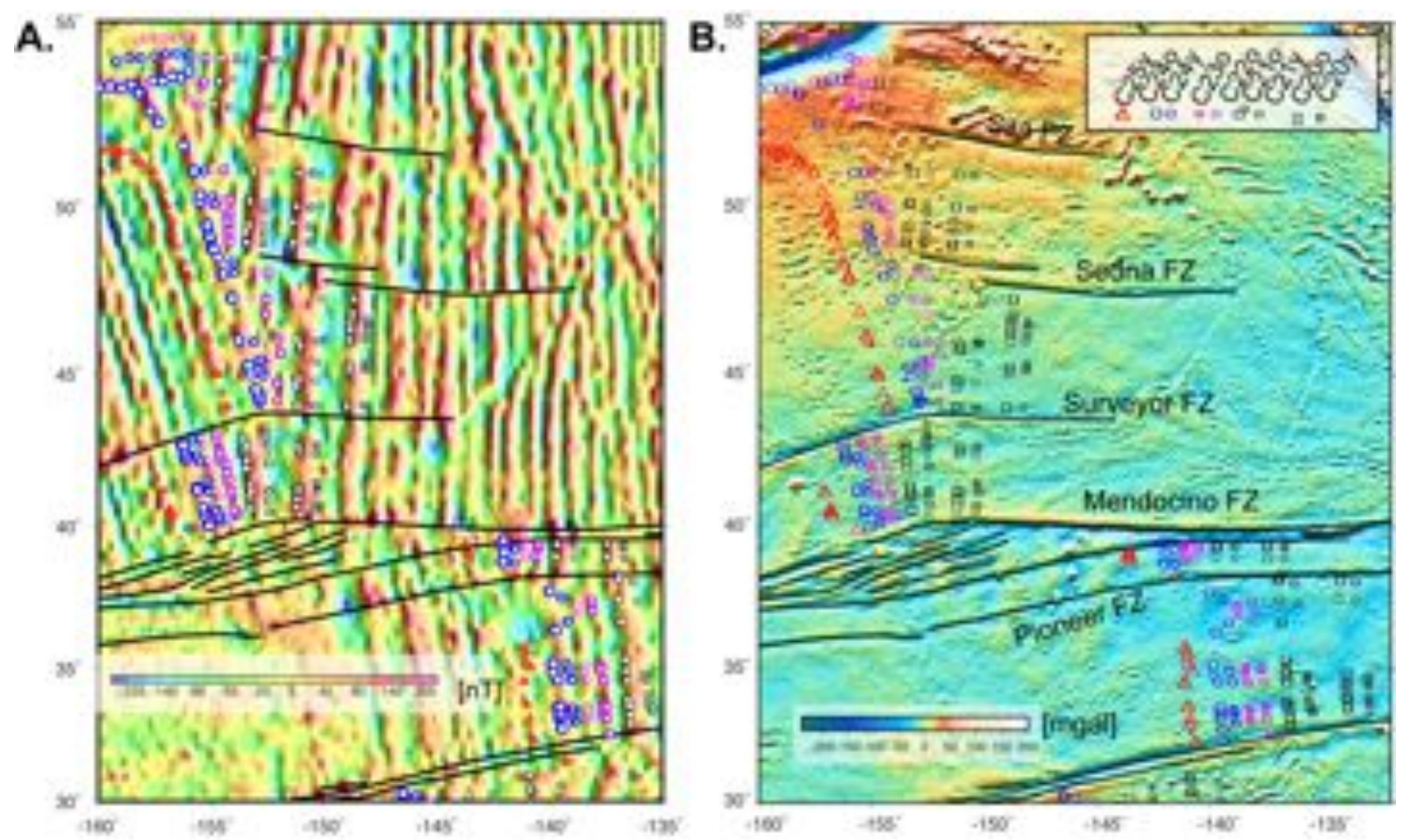

1005

1006 Fig. 8. A. Magnetic anomaly grid (Meyer et al., 2017), and B. Free air gravity 1007 anomaly derived from satellite altimetry (Sandwell et al., 2014) for NE Pacific, north 1008 of Mendocino fracture zone system (see location in Fig. 4). Various symbols show the 1009 distribution of magnetic anomaly picks used to derive the regional isochron model. 1010 Black lines are fracture zone identifications (Matthews et al., 2011).

1011

1012 
A.

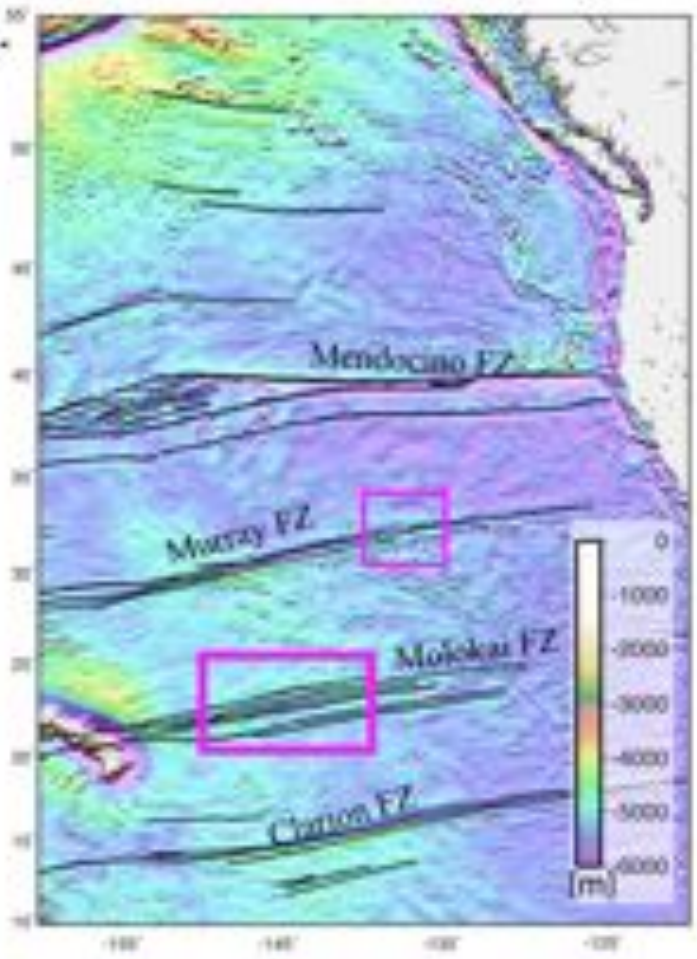

C.

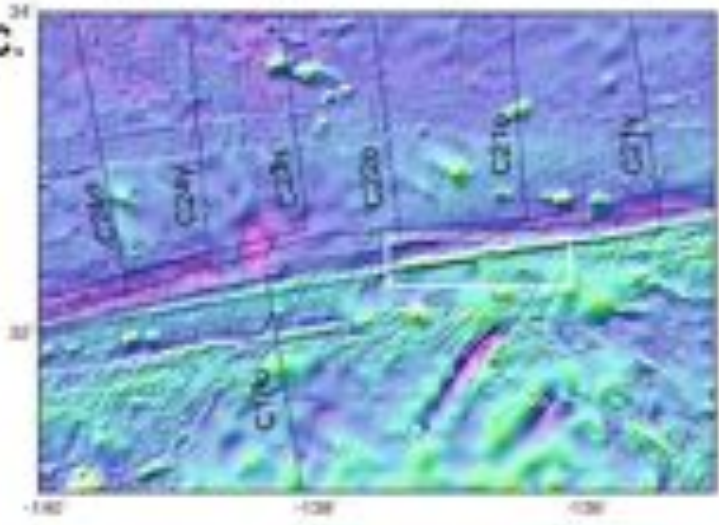

E.

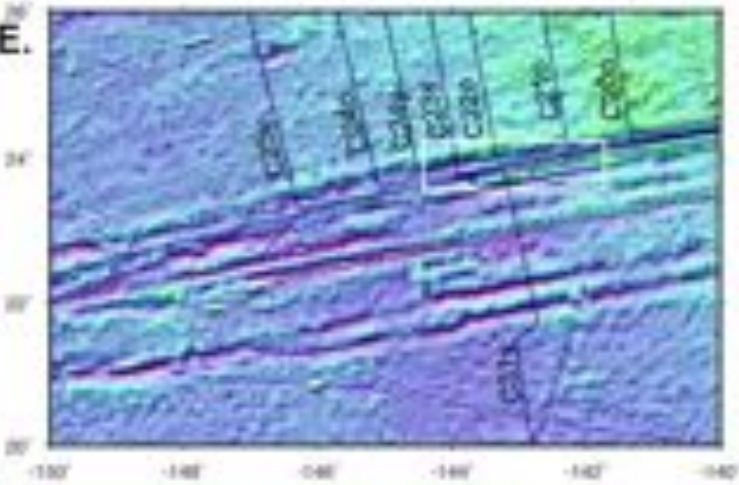

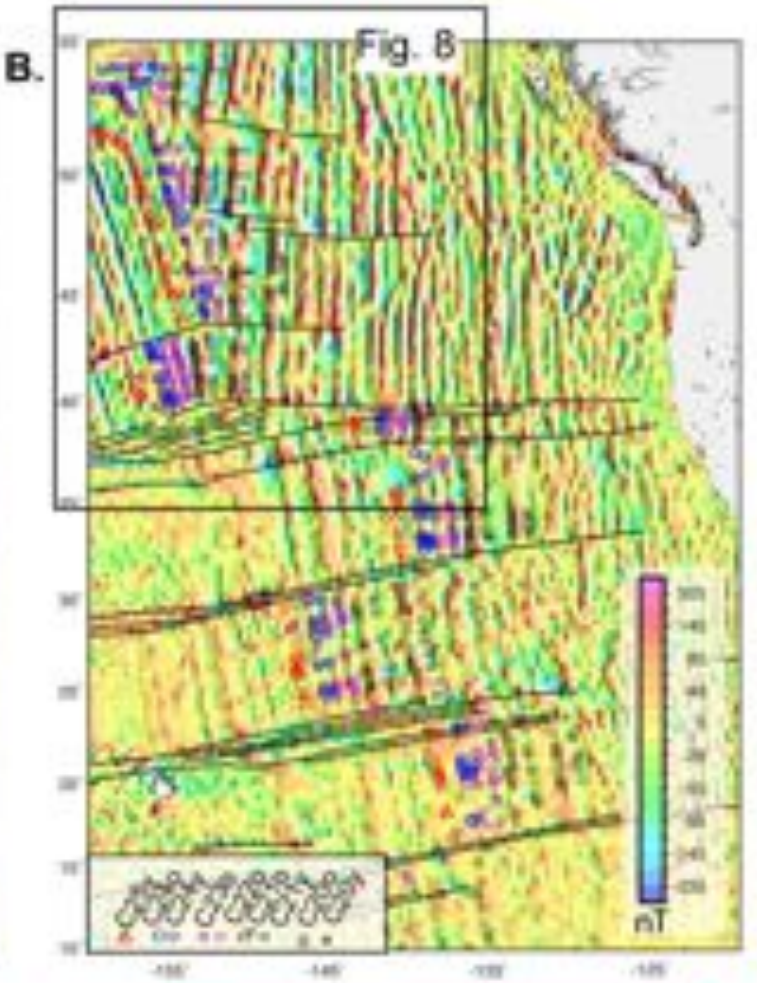

D.

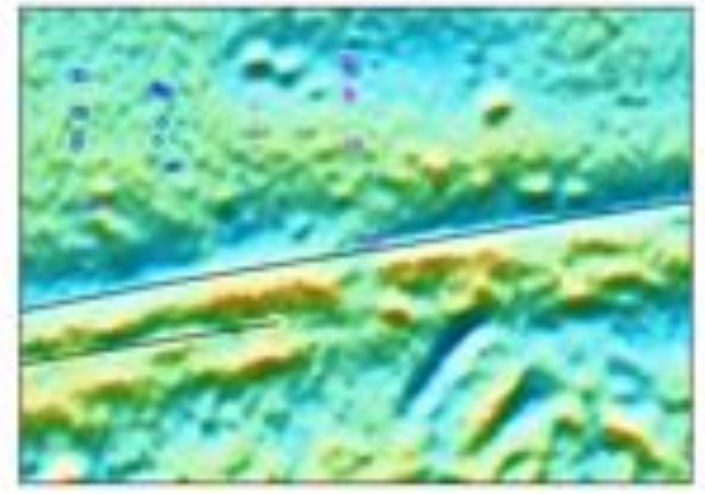

F.

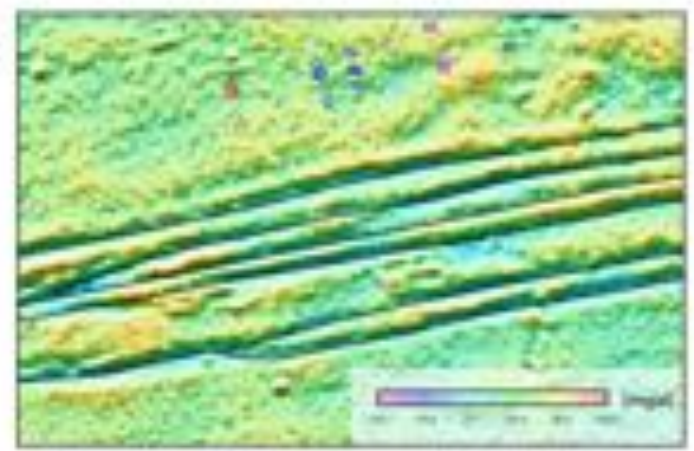

1014 Fig. 9. A. Bathymetry (Ryan et al., 2009) of NE Pacific (north of Clarion fracture 1015 zone), and B. Magnetic anomaly grid (Meyer et al., 2017). C and E show bathymetry 1016 and multibeam data (Ryan et al., 2009, GMRT 2017 version) for selected fracture 1017 zone segments (see text for more details). D and F show free air gravity anomaly 
1018 (Sandwell et al., 2014) for the same regions. Various symbols show the distribution of 1019 magnetic anomaly picks used to derive the regional isochron model. Thick black lines 1020 are fracture zone identifications (Matthews et al., 2011) and thin lines are isochrons 1021 (this study). White boxes indicate the areas along fracture zone segments with 1022 transition from extension to compression associated with changes in relative plate 1023 motions. 


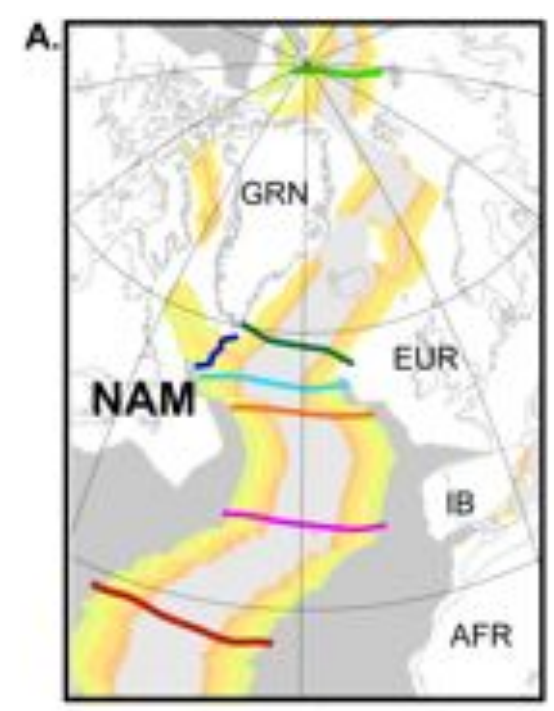

c.
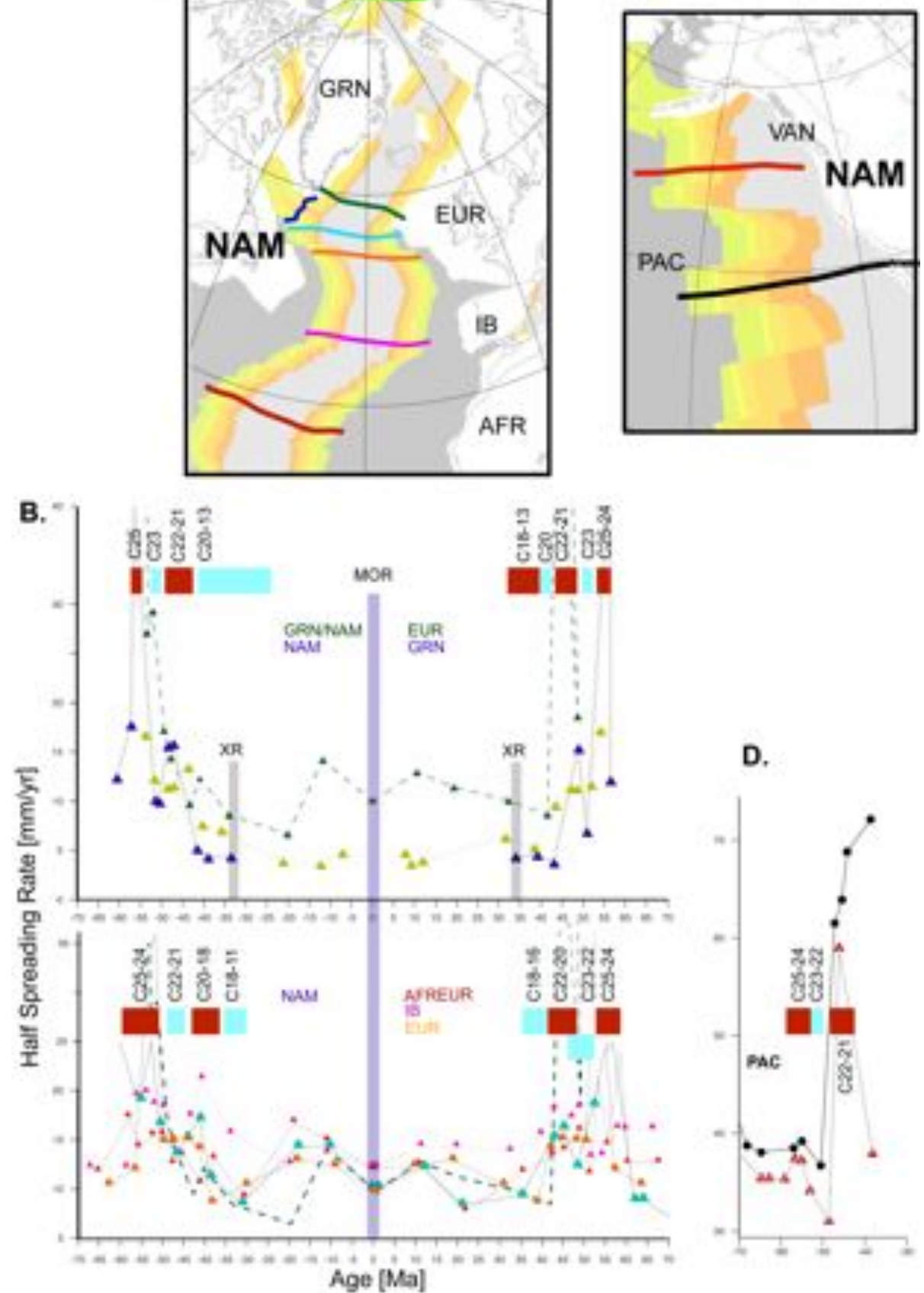

D.

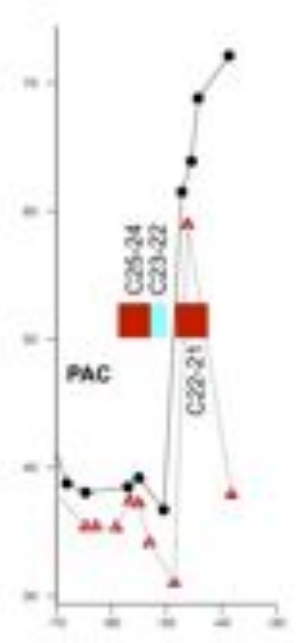

Fig. 10. Seafloor spreading rate variations for the Eocene to Present in the Atlantic and Arctic (A and B), and for Eocene to Oligocene in the NE Pacific (C and D). Coloured lines on maps $\mathrm{A}$ and $\mathrm{C}$ show colour-coded flowlines, which were used as profiles to extract seafloor-spreading rate values in various oceanic sub-basins.

1031 The upper graph in panel B shows spreading rates in the Arctic region (olive symbols), NE Atlantic (green symbols), and Labrador Sea (blue symbols). MOR is

1033 mid-ocean ridge. The lower graph shows spreading rates in North Atlantic (coloured 1034 symbols from north to south: light blue, orange, magenta and red). For comparison, 1035 the values from NE Atlantic (in dark green) are also plotted in this panel. Red 
1036 polygons indicate periods of seafloor-spreading rate increase, and blue polygons 1037 indicate seafloor-spreading rate decrease.

1038 

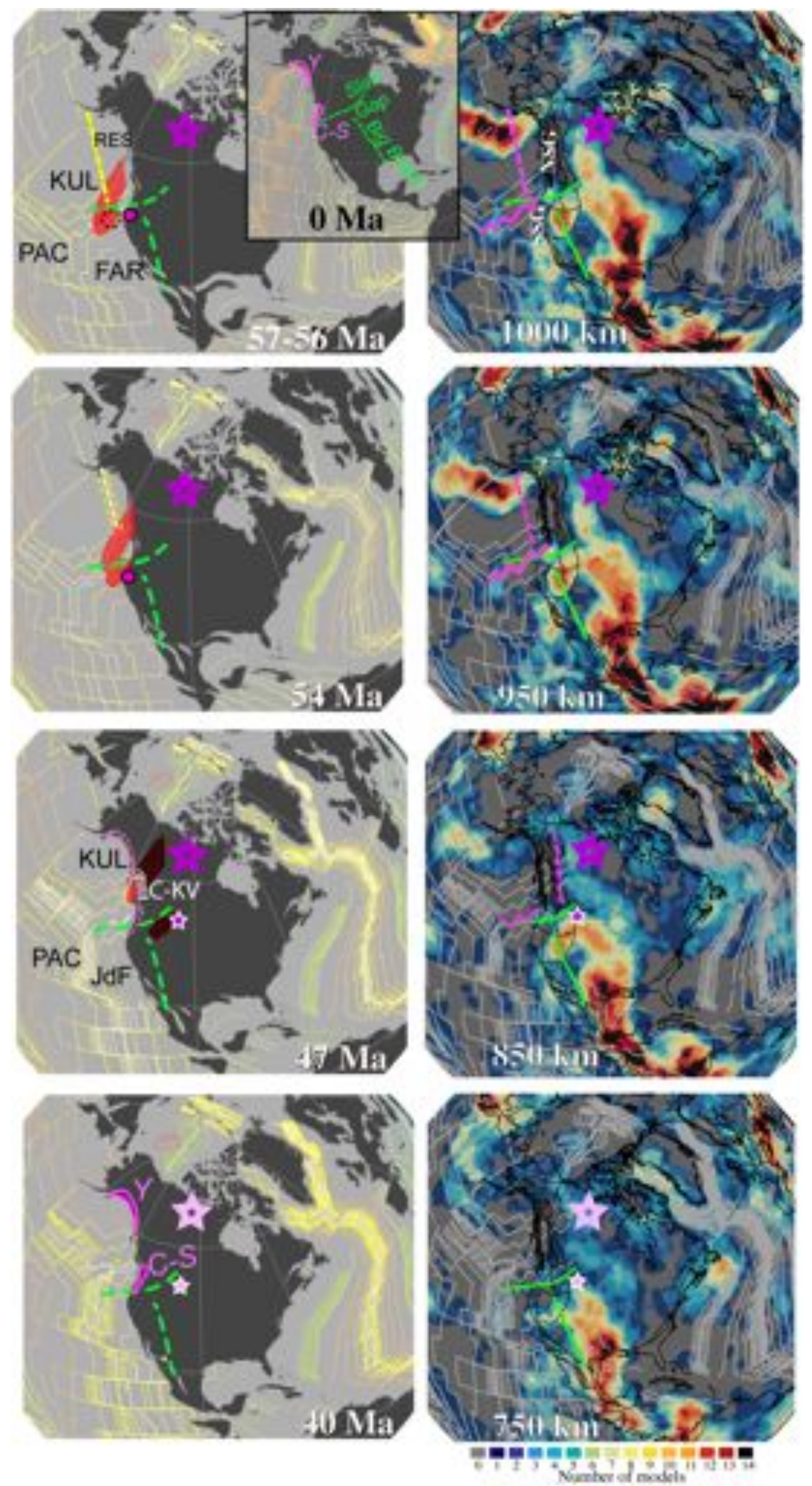
1040 Fig. 11. Tectonic plate reconstructions in an absolute reference frame (left panels) and 1041 subducted slab distribution ("vote maps", Shephard et al., 2017) in the lower mantle 1042 (right panels). The continents (dark grey) are outlined by present-day coastlines 1043 (black, thin lines); the isochron color scale on right panels follows the magnetic pick 1044 color scheme from Fig. 1. Siletzia (“S”) and Crescent (“C") accreted terrane outline 1045 (pink outlines) and approximate extent of the original Siletzia-Crescent-Yakutat LIP 1046 (red polygons) are modified after Wells et al., (2014). The LIP was partly accreted 1047 (pink dashed lines) and probably also subducted (dark brown polygons) on and under 1048 the North American plate. Light green lines show the Sigloch et al., (2008) and 1049 Sigloch (2011) interpretation of slab gap boundaries (as in the inset upper panel). The 1050 magenta circle shows the approximate location of the Yellowstone hotspot, the black 1051 dotted circle in the upper left panel indicate its possible position due to mantle 1052 advection. The magenta star symbols indicate the reconstructed locations of Eocene 1053 kimberlite eruption sites (big star-Canadian location, smaller star-US location). The 1054 pale stars in the lower panels indicate inactive kimberlite sites. The reconstructed 1055 positions of mid-ocean ridges in the NE Pacific are shown as magenta segments on 1056 right panels. Abbreviations are: FAR-Farallon, JdF-Juan de Fuca, KUL-Kula, PAC1057 Pacific, Res-Resurrection plates, C-Crescent, C-KV-Challis-Kamloops volcanic belt, 1058 S-Siletzia, Y-Yakutat. 